\title{
GEOGRAFISKA
}

ANNALER

SERIES A PHYSICAL GEOGRAPHY

\section{Deformational behaviours of alluvial units detected by Advanced Radar Interferometry in the Vega Media of the Segura River, southeast Spain}

\begin{tabular}{|c|c|}
\hline Journal: & Geografiska Annaler: Series A, Physical Geography \\
\hline Manuscript ID & GAA1503-016.R1 \\
\hline Wiley - Manuscript type: & Original Article \\
\hline Date Submitted by the Author: & $\mathrm{n} / \mathrm{a}$ \\
\hline Complete List of Authors: & $\begin{array}{l}\text { Conesa-García, Carmelo; University of Murcia, Department of Physical } \\
\text { Geography } \\
\text { Tomás, Roberto; University of Alicante, Department of Civil Engineering } \\
\text { Herrera, Gerardo; Geological and Mining Institute of Spain, Geohazards } \\
\text { Remote Sensing Laboratory } \\
\text { López-Bermúdez, Francisco; University of Murcia, Department of Physical } \\
\text { Geography } \\
\text { Cano, Miguel; University of Alicante, Department of Civil Engineering } \\
\text { Navarro-Hervás, Francisca; University of Murcia, Department of Physical } \\
\text { Geography } \\
\text { Pérez-Cutillas, Pedro; Superior Council of Scientific Research (CSIC), }\end{array}$ \\
\hline Keywords: & Alluvial forms, Deformation rates, A-DInSAR \\
\hline Abstract: & $\begin{array}{l}\text { It is widely known that differential land subsidence in a valley significantly } \\
\text { controls its fluvial dynamics. Nevertheless, major uncertainty exists about } \\
\text { the way in which alluvial forms respond to this process. In this study, } \\
\text { morphological and lithostratigraphic data have been combined with } \\
\text { Advanced Differential Interferometry (A-DInSAR) to detect changes in } \\
\text { alluvial landform elevations and to verify the existence of a differential } \\
\text { subsidence pattern influenced by active sedimentary dynamics. For this } \\
\text { purpose, the middle reach of the Segura River valley (Vega Media of the } \\
\text { Segura River, VMSR), in south-east Spain, was chosen as the study area. } \\
\text { The VMSR is an alluvial area affected by subsidence processes in close } \\
\text { conjunction with depositional conditions, ground-water withdrawals and } \\
\text { faults. A high scale mapping of the main younger sedimentary units was } \\
\text { carried out by combining multi-temporal aerial photographs, high } \\
\text { resolution DEMs derived from LIDAR data, GNSS data and field work. In } \\
\text { addition, lithostratigraphic descriptions were obtained from geotechnical } \\
\text { drilling and trenching. Finally, ground surface displacements, measured } \\
\text { using A-DInSAR for the periods } 1995-2005 \text { and } 2004-2008 \text {, allowed the } \\
\text { determination of elevation rates and ground deformation associated with } \\
\text { the different alluvial units. The results from this analysis revealed four } \\
\text { typical deformational behaviours: a) Non-deformational units (cemented } \\
\text { alluvial fans and upper fluvial terraces); b) Slightly deformable units (lower } \\
\text { terraces and old abandoned meanders); c) Moderately deformable units } \\
\text { (lateral accretion zones and abandoned meanders before channelisation in }\end{array}$ \\
\hline
\end{tabular}


1981); and d) highly deformable areas (recently active meanders associated with artificial cutoffs by channelisation, non-active floodplains and spilling zones).

\section{SCHOLARONE \\ Manuscripts}


1 DEFORMATIONAL BEHAVIOURS OF ALLUVIAL UNITS DETECTED

2

\title{
BY ADVANCED RADAR INTERFEROMETRY IN THE VEGA MEDIA
} OF THE SEGURA RIVER, SOUTHEAST SPAIN

\author{
CARMELO CONESA-GARCÍA ${ }^{1}$, ROBERTO TOMÁS ${ }^{2}$, GERARDO HERRERA ${ }^{3}$, FRANCISCO LÓPEZ- \\ BERMÚDEZ ${ }^{1}$, MIGUEL CANO ${ }^{2}$, FRANCISCA NAVARRO-HERVÁS ${ }^{1}$ and PEDRO PÉREZ-CUTILLAS ${ }^{1,4}$
}

\footnotetext{
${ }^{1}$ Department of Physical Geography, University of Murcia, Murcia, Spain.

${ }^{2}$ Department of Civil Engineering, Higher Polytechnic School, University of Alicante, Alicante, Spain. ${ }^{3}$ Geohazards Remote Sensing Laboratory, Geological and Mining Institute of Spain, Madrid, Spain.

${ }^{4}$ Centre of Soil Science and Applied Biology of the Segura River, Superior Council of Scientific Research, Murcia, Spain.
}

\section{Abstract}

It is widely known that differential land subsidence in a valley significantly controls its fluvial dynamics. Nevertheless, major uncertainty exists about the way in which alluvial forms respond to this process. Alluvial sediments constitute loose and unconsolidated deposits characterized by their low strength and bearing capacity. These sedimentary units have a moderate to very high compressibility, which depend mainly on the physical properties of the sediments and depositional environments. In this study, morphological and lithostratigraphic data have been combined with Advanced Differential Interferometry (A-DInSAR) to detect changes in alluvial landform elevations and to verify the existence of a differential subsidence pattern influenced by active sedimentary dynamics. For this purpose, the middle reach of the Segura River valley (Vega Media of the Segura River, VMSR), in south-east Spain, was chosen as the study area. The VMSR is an alluvial area affected by subsidence processes in close conjunction with depositional conditions, ground-water withdrawals and faults. A high scale mapping of the main younger sedimentary units was carried out by combining multi-temporal aerial photographs, high resolution DEMs derived from LIDAR data, GNSS data and field work. In addition, lithostratigraphic descriptions were obtained from geotechnical drilling and trenching. Finally, ground surface displacements, measured using A-DInSAR for the periods 1995-2005 and 2004-2008, allowed the determination of elevation rates and ground deformation associated with the different alluvial units. The results from this analysis revealed four typical deformational behaviours: a) Non-deformational units (cemented alluvial fans and upper fluvial terraces); b) Slightly deformable units (lower terraces and old abandoned meanders); c) Moderately deformable units (lateral accretion zones and abandoned meanders before channelisation in 1981); and d) highly deformable areas (recently active meanders associated with artificial cutoffs by channelisation, non-active floodplains and spilling zones).

Keywords A-DInSAR, alluvial sediments, morphological units, lithostratigraphy, land subsidence, Vega Media of the Segura River, Spain. 
Differential Synthetic Aperture Radar Interferometry (DInSAR) is a radar remote sensing technique that enables the measurement of surface displacement with a centimetre to millimetre accuracy and with a large spatial coverage capability. It exploits the phase difference between two SAR (Synthetic Aperture Radar) images acquired over the same area in different epochs, providing measurements of the ground displacement component along the radar line of sight (LOS). Advanced DInSAR (A-DInSAR) techniques compute displacement time series from the multi-image analysis, typically a few dozen SAR images. A review of the application of these techniques to the detection and measurement of different types of subsidence phenomena (mining, sinkholes, ground water withdrawal and those related to volcanic environments) was elaborated by Tomás et al. (2014). The use of DInSAR for the study of subsidence due to aquifer abstraction was applied first by Galloway et al. (1998), and subsequently to other aquifer systems worldwide. These works document: (1) the spatial and temporal evolution of aquifer deformation (Galloway and Hoffmann 2007; Heleno et al. 2011; Herrera et al. 2009a; Cigna et al. 2012; Raspini et al. 2012; Stramondo et al. 2008; Tomás et al. 2005; Vilardo et al. 2009; Peduto et al. 2015); (2) numerical models capable of reproducing aquifer related subsidence (Calderhead et al. 2011; Herrera et al. 2009b; Hoffmann et al. 2003; Raspini et al. 2014; Tomás et al. 2010); (3) urban areas and structures affected by ground subsidence (Karila et al. 2005; Cascini et al. 2007; 2013; Bru et al. 2010; Herrera et al. 2010; Tapete et al. 2012; Tomás et al. 2012; Sousa et al. 2013; Sanabria et al. 2014). Within this regional context of subsidence induced by groundwater abstraction, there are no previous works targeting different deformational behaviours in alluvial forms with different lithofacies and sediment ages. Therefore, we propose the combination of A-DInSAR displacement measurements with lithostratigraphic data and precise LIDARderived Digital Elevation Models (DEM) as a complementary tool for monitoring deformation and elevation rates of alluvial morphological units. For this purpose, the Vega Media of the Segura River (VMSR) has been chosen as the study area. In this area, A-DInSAR has been broadly applied to measure, characterise and model regional subsidence triggered by water withdrawal (Herrera et al. 2009a, 2009b, 2010; Tomás et al. 2005, 2010, 2011). However, it has not yet been used to detect different deformation patterns in the alluvial forms. The study of this differential ground deformation in relation to natural consolidation processes or those induced by groundwater extractions is crucial in alluvial valleys having a high population pressure. Buildings and civil infrastructures can be seriously damaged by these processes. The deformation is often presumed to be continuous. However, in many of these valleys the subsidence of buildings in urban areas is non-continuous, due not only to differences in their foundations but also to their settlement on alluvial units of uneven consistency. In these cases, the major advantage of the A-DInSAR techniques over measurements of leveling would be the more extensive and frequent monitoring of the subsiding units. dynamics.

\section{Study area}


The Vega Media of the Segura River (VMSR) $\left(100 \mathrm{~km}^{2}\right)$ is located at the eastern end of the Betic Cordillera, in the Lower Segura valley. This area lies over the contact between the Internal and External Zones (Montenat 1977; Fig. 1), and as a result it participates in the geo-tectonic features of both domains. Consequently, the materials on the southern border of the VMSR (Internal Zone) consist of Permian-Triassic rocks, Neogene materials and Pleistocene colluvial deposits. In contrast, the northern border (External Zone) is mainly made up of sedimentary rocks (marls, sandstones and conglomerates) belonging to the Upper Miocene-Pliocene. Normal faults and strike slip faults occurred from the pre-Tortonian up to the Quaternary in the Internal Zone, while the External Zone was dominated by a Neogene compressive deformation. In this context, the VMSR makes up part of the extensive valley in an ENE-WSW direction, controlled by active faults, particularly the Crevillente fault to the north and the Carrascoy fault to the south. The mountainous fronts that border the valley were elevated by the reactivation of both faults in the final Miocene period, and were touched up by the tectonic activity that is still active today (Alfaro 1995; Rodríguez-Estrella et al. 1999). Since the Pliocene epoch, several generations of alluvial fans have developed at the base of these mountainous fronts (Goy and Zazo 1989), their most recent formations (Later Pleistocene - Holocene) converging laterally in the alluvial plain of the Segura River.

As a result of neotectonic processes, variations in the sea level (Soria et al. 2001) and the considerable supply of sediments generated by the Segura and Guadalentín Rivers during the Pleistocene and Holocene epochs, the valley has a thick alluvial filling in the study area.The most recent deposits from the alluvial units within this area, mainly composed of silts, clays and sands as described in detail in next sections, are potentially deformable and also include the most problematic type of sediment from a geotechnical point of view (i.e. the most unconsolidated and deformable when affected by an increase in effective stress). Rodríguez Jurado et al. (2000), Mulas et al. (2003) and Tomás (2009) made geotechnical characterisations of all these materials for the VMSR based on boreholes logs, laboratory tests performed on undisturbed samples and in situ tests. They showed that the sedimentary rocks protruding at the valley borders, which are also found at some depth within the floodplain, are characterised by low to negligible compressibility, while, above them, the recent shallow sediments exhibit moderate to high compression capacity.

\section{Alluvial forms used in the analysis}

In this study the following adjacent alluvial units have been defined and delineated in the VMSR: i) active channels for different dates (ACH 192X, ACH 1956, ACH 1981, ACH 2009); ii) lateral accretion zones (LAC); iii) artificial cut-offs by channelisation in 1981 (AC); iv) abandoned meanders before channelisation (AMP); v) non-active floodplain and spilling zones (FP-SP); vi) fluvial terraces (T, G-T and SG-T); and vii) alluvial fans (AF, GAF and AFG). Aerial photographs showing some of these alluvial units are included in Fig. 2.

i) Active channels (ACH 192X, ACH 1956, ACH 1981, ACH 2009) refer to reaches of the Segura River which had geomorphological activity in these years and soon ceased to be functional.

ii) Lateral accretion zones ( $L A C$ ) observed during 1956. For the present study, we have considered the surface demarcated in 1956, shortly after the great flood of 1948, which caused considerable morphological changes throughout the Lower Segura River. According to this demarcation, the development of the LAC was significant $3-4 \mathrm{~km}$ upstream from the city of Murcia. 
118

119

120

121

122

123

124

125

126

127

128

129

130

131

132

133

134

135

136

137

138

139

140

141

142

143

144

145

146

147

148

149

150

151

152

153

154

155

156

157

iii) Unit $A C$ is composed of artificial cutoffs and isolated meanders produced during the 1981 channelisation.

iv) Abandoned meanders before channelisation (AMP). Before channelisation in 1981, the fluvial planform of the Lower Segura River was a classic meandering channel pattern, associated with sediment-laden fine-grained flows and sandy bed loads, which was slightly modified by the partial confinement of embankments or levees. The construction of a large number of reservoirs in the headwater area, during the 20th century, has considerably reduced the sediment transport during flood events, especially coarse material loads.

v) Non-active floodplain and spilling zones (FP-SP). These are areas affected by the overflowing of the Segura River during flood events or the breakage of the levees that protect its banks. As an example, we demarcated for the period 1879-1956 the surface corresponding to these alluvial units using borehole data and aerial photographs.

vi) Fluvial terraces ( $T, G-T$ and $S G-T)$. The best defined fluvial terraces within the VMSR are mostly concentrated on its extreme northwestern side, in the area known as La Contraparada, Alcantarilla (Fig. 1). This is the narrowest part of the VMSR, being flanked by modest reliefs which originated in post-Miocene times. Along this reach, the Segura registered several phases of aggradation and incision during the Quaternary period associated with different climatic fluctuations and tectonic manifestations. The result is a system of alluvial terraces, built on a base of continental conglomerates from the Late Miocene. This system consists of three terrace levels with a height ranging between 14 and $21 \mathrm{~m}$ above the current river thalweg: T1 $(21 \mathrm{~m}), \mathrm{T} 2(17 \mathrm{~m})$ and $\mathrm{T} 3(14 \mathrm{~m})$.

These fluvial terraces are found on both banks of the river. To the north, on the left bank of the river, the upper terrace level comes into lateral facies contact with an alluvial piedmont plain from the Pleistocene (G-T1). However, on the right bank located further to the south, the lowest terrace passes laterally to a mixed alluvial unit composed of fine materials which were deposited by the Segura River and its main tributary, the Guadalentín River (SG-T3). This sector functioned as a convergence zone for both fluvial systems throughout the Holocene (Calmel-Avila 2000), but has now lost this feature. In fact, its vertical sediment accretion has been practically interrupted due to human activity in the last two centuries (construction of reservoirs upstream and by-pass channels).

vii) Alluvial fans (AF, GAF and $A F G$ ). This unit consists of a group of alluvial sedimentary bodies extended into a fan shape from the surrounding sierras and from the Lower Guadalentín River. These are grouped into three subunits with different morphology and sedimentary facies: AF, alluvial fans developed on the north side of the Sierra de Carrascoy, which includes the AF1 system to the West and the AF2 system to the East; GAF, the Guadalentín River alluvial fan joining the Segura River; and AFG1 and AFG2, alluvial fans bordered to the East by the GAF subunit.

AF subunits. These alluvial fans are affected by the Carrascoy Fault, so that their apical areas have great thickness (more than $40 \mathrm{~m}$ in the AF1 system) and high longitudinal slopes ( $>0.12$ ). They participate in many of the features that characterise this type of landform in the Internal Zone of the Betic Cordillera. In this area, eustatic cycles, together with different rates of subsidence or uplift, have led to a complicated pattern of allogenic control over the stratigraphic architecture and the distribution of sedimentary facies in alluvial fan systems (Harvey 1990; Silva et al. 1992; Calmel-Avila 2002).

GAF Subunit. This refers to an extensive and lengthened alluvial fan constructed by fine sediments from the Guadalentín River on reaching the Segura. This is a progradant interior delta over the alluvial plain of the 
158

159

160

161

162

163

164

165

166

167

168

169

170

171

172

173

174

175

176

177

178

179

180

181

182

183

184

185

186

187

188

189

190

191

192

193

194

195

196

197

VMSR, generated during the Late Pleistocene-Holocene by overflows from distributary channels at the end of the Guadalentín (DCH-G).

AFG subunits. These form a system of coalescent alluvial fans of hardly any thickness at all. Its sediment source areas belong to mountainous fronts of moderate energy caused by postmantle deformations that affected materials from the Miocene age (sandstones, conglomerates and marls). Recent tectonic manifestations, in the upper Pleistocene and Holocene, associated with the Alhama-Alcantarilla fault, affected the local base level of several left-bank tributaries of the Guadalentín, thus speeding up erosion processes upstream and increasing influxes of sediment into the main collector. Nevertheless, this side is less tectonically active than the southern one and leads to the formation of lower-gradient alluvial fans (gradient less than 0.12).

\section{Data and methods}

\section{Lithostratigraphic data}

Borehole stratigraphic logs and data are often used for detecting subsidence processes in plains and urban areas (Cinti et al. 2008; Dang et al. 2014). In this study, descriptions have been used from geological columns of a total of 46 deep boreholes and 385 geotechnical and hydrogeological surveys of 15 to $20 \mathrm{~m}$ depth available for the VMSR. The boreholes were made by the Hydrographic Confederation of the Segura (CHS, Ministry of Environment), the Geological Survey of Spain (Ministry of Science and Innovation), EMUASA, the Municipal Water and Sanitation Company of Murcia, and various specialized geotechnical companies. The drilling method commonly employed was recovery rotational rolling control. Due to the low consistency of the material traversed, it was decided in many cases to drill dry, thus facilitating better recognition of the stratigraphy. The work included test drilling "in situ", specifically dynamic standard penetration (SPT) and the cone penetrometer test (CPT). Geotechnical reports and studies provided by the Official College of Architects of Murcia, the Directorate General of Heritage (Autonomous Community of the Region of Murcia) and different testing laboratories were collected. From each geotechnical report, data relating to particle size, plasticity limits, natural moisture content, compressive strength, porosity index, consolidation ratio and dry density were taken. With the information collected, we developed our own database, operated from ArcGIS for the analysis and spatial correlation of the lithostratigraphic columns across the VMSR.

In addition, field work was performed to determine the main lithofacies of the alluvial forms (e.g. fluvial terraces and alluvial fans) remaining visible through holes and trenches dug as part of civil works. These lithofacies were referred to using the codes and descriptions proposed by Miall (1996) (Table 1) and different granulometric parameters were computed: the median grain size $\left(D_{50}\right)$, the size of the coarse fraction represented by $D_{84}\left(84^{\text {th }}\right.$ percentile), and the sediment classification according to Trask's Sorting Index.

\section{Delineating spatial boundaries and mapping alluvial forms}

In order to map the alluvial units, aerial photographs from the following flights were selected: Ruiz de Alda at $1 / 10000$ scale (1928), USAF56 at 1/30000 scale (1956), the Regional Government of Murcia at 1:18000 scale (1981) and the PNOA (National Plan of Aerial Orto-photography) at high resolution (2009). The demarcation of 
198

199

200

201

202

203

204

205

206

207

208

209

210

211

212

213

214

215

216

217

218

219

220

221

222

223

224

225

226

227

228

229

230

231

232

233

234

235

236

237

the alluvial forms identified from the photo-interpretation has been validated in the field with the support of the Global Navigation Satellite System (GNSS), using a Trimble positioning receptor (geoXT model), achieving sub-metric precision. Field data correction was carried out using Trimble's Pathfinder Office 4.2 software with RINEX data acquired by the Meristemum Network Service's GNSS of the General Directorate for the Environment of the Regional Government of Murcia.

Additionally, in order to complement the spatial mapping of the alluvial forms, a Digital Elevation Model was elaborated with a $1 \mathrm{~m}$ pixel resolution using LIDAR data (PNOA, 2009). The PNOA mission used a RieglLMSQ680 sensor, which provided the following technical features: a nominal density of 0.5 points per square metre, a nominal distance between points of $1.4 \mathrm{~m}$, and an altimetric precision of the RMSE point cloud of less than $0.20 \mathrm{~m}$. The retrieved LIDAR data were processed using the freely available software FUSION LIDAR/IFSAR v. 2.9 of the Forestry Service of the US Department of Agriculture (USDA).

\section{Advanced Radar Interferometry (A-DInSAR)}

Stable Point Network (SPN) is an advanced differential interferometric processing technique (A-DInSAR) that incorporates both the Persistent Scatterer (PS) and Small Baseline (SB) approaches (Arnaud et al. 2003, Duro et al. 2005). The basis of the SPN technique is the separation of the different components of the phase difference: displacement, topographic error, atmospheric effects and the uncertainties in the sensor precise orbit information. The SPN software uses the DIAPASON interferometric algorithm for handling SAR data (e.g. co-registration and interferogram generation). Linear model fitting methodologies generate three main products starting from a set of Single Look Complex (SLC) SAR images: (a) the average displacement velocity along the line of sight (LOS) of every persistent scatterer (PS); (b) a map of precise reflector heights (the difference between the heights being given by the digital elevation model and the true height of each reflector; and (c) the LOS displacement time series of each individual PS. A minimum number of images is required, depending on the wavelength of the SAR sensor, the considered time period, and the temporal lapse among SAR image acquisitions. An increase in the number of images contributes to the improvement of the quantity and accuracy of the displacement results.

In this study the full resolution approach has been used to select the suitable measurement points (PSs) due to the high electromagnetic response of the radar signal (backscattering) in urban environments such as Murcia city. The SPN algorithm has been applied to images acquired from descending orbits by the European Space Agency (ESA) ERS-1/2 and Envisat ASAR sensors, covering two periods: July 1995-October 2005 and January 2004December 2008 (Table 2). A crop of about $20 \mathrm{~km} \mathrm{x} 8 \mathrm{~km}$ was selected from the $100 \mathrm{~km}$ x $100 \mathrm{~km}$ SAR images acquired, corresponding to the VMSR (Fig. 1). Each interferometric pair has been selected with a perpendicular spatial baseline of less than $800 \mathrm{~m}$, a temporal baseline shorter than 6 years in the case of 1995-2005 and 3 years in the case of 2004-2008 and a relative Doppler centroid difference of under $400 \mathrm{~Hz}$. The DEM of the Shuttle Radar Topography Mission (SRTM) has been used. The pixel selection for the estimation of displacements was based on a combination of several quality parameters including low amplitude standard deviation and high model coherence. The SPN technique permitted to detect a total amount of 31474 and 20460 PS within the VMSR (200 $\mathrm{km}^{2}$ area) for both analysis periods. The validation experiments (Herrera et al., 2009a,b and Tomás et al., 2011) performed between SPN displacement measurements and the extensometric network of Murcia, 
provided a similar cumulative error $( \pm 6 \mathrm{~mm})$ for the periods 1995-2005 and 2004-2008. In line with this, we define the stability range between $-6 \mathrm{~mm}$ and $+6 \mathrm{~mm}$ of cumulated displacement. Hereafter subsidence will be referred to as DInSAR negative displacement measurements, whereas positive displacement measurements will be referred to as uplift.

The maps of the cumulative displacement in August 2005 and December 2008, estimated along the LOS, and obtained by the SPN technique for both periods, are presented in Fig. 3. Note that the measurements along the LOS underestimate the vertical displacement caused by land subsidence as mentioned by Vilardo et al. (2012), Cascini et al. (2013) and Peduto et al. (2015). In order to analyse the relationship between the fluvial units the subsidence rates have been compared considering different parameters (present distance from the river, meander abandonment phase and type of filling sediment). The average and standard deviation of the deformation rates were measured in Persistent Scatterers (PSs) included within these units. Table 3 shows the area and the coverage of InSAR for the different alluvial units considered in the analysis. In the following section displacement measurements have been spatially compared with the previously mapped alluvial units in the VMSR. Note that some uncertainties are inherent to this approach because ground surface displacements also depend on the effective stress change caused by water level decline. However, for a similar water level decrease more compressible sediments may cause larger expected settlements.

\section{Historical changes in alluvial landform elevations based on lithofacies and A-DInSAR data}

The spatial analysis of the cumulative displacement distribution in the different mapped morphological units (Fig. 3) allowed the computation of the mean subsidence rate, the standard deviation and the extreme values (i.e. maximum and minimum) for each unit (Fig. 4). It is assumed that the mapped alluvial units were affected by a similar water level drop for each temporal period under study (i.e. 5-8 m for 1995-2005 and 4-6 m for 20042008; Mulas et al. 2010), and as a consequence their compressibility mainly depends on the soft sediment thickness of each morphological unit. It is worth noting that this assumption could be locally modified due to point withdrawals and spatial changes on infiltration due to rainfall or irrigation, although the induced stress change can be considered quite uniform at basin scale. For both periods analysed, the maps of cumulative displacement estimated along the LOS (Fig. 3) revealed that subsidence was more intense in the floodplain of the Segura River, especially to the northeast and south of Murcia city - where values of cumulative subsidence around $120 \mathrm{~mm}$ and $65 \mathrm{~mm}$, respectively, were recorded. Overall, the subsidence phenomenon in the period 2004-2008 (5 mm/yr on average) was more intense than that of the period $1995-2005$ ( $2 \mathrm{~mm} / \mathrm{yr}$ on average).

Fig. 4 shows that the greatest mean accumulated displacements (from -11.6 to $-15 \mathrm{~mm}$ for the period 1995-2005 and from -22.2 to $-30.4 \mathrm{~mm}$ during 2004-2008) occurred in the PSs within the more recently active channels (ACH 1956, ACH 1981, ACH 2009). It supposes a maximum average subsidence rate of 4.44 to $6.09 \mathrm{~mm} / \mathrm{year}$ for the second analysis period. In this period, the standard deviation values were also higher for this unit (16.3 to 20.9). The course of these channels seems to be restricted by a fringe or a meander belt which suffered an important piezometric decrease between 2005 and 2007 (Mulas et al. 2010). In 2004, the Hydrographic Authority drilled a total of 24 deep wells to maintain water supplies during drought periods (CHS 2007a). At least $80 \%$ of them were drilled less than $1000 \mathrm{~m}$ from the river channel. These wells currently withdraw 
278

279

280

281

282

283

284

285

286

287

288

289

290

291

292

293

294

295

296

297

298

299

300

301

302

303

304

305

306

307

308

309

310

311

312

313

314

315

316

important water flows from the deep aquifer (gravel unit) (average depth $>240 \mathrm{~m}$ ), pumping 80-160 1/s (CHS 2007a). In addition, at distances of less than $2000 \mathrm{~m}$ from the river course, 38 wells were drilled for urban purposes, as well as six industrial wells with shallower depths and 37 legalised agricultural wells with an average pumping discharge of 55 1/s (CHS 2007a). This intense exploitation of the VMSR aquifer system near the Segura River could explain the high subsidence rate registered in this area during the second study period.

Regardless of the effects attributed to the variations in the piezometric level, it is obvious that the geomorphologic behaviour of these units clearly differs from that of the units located further away from the river. The successive channelisations performed during the 20th century have produced a remarkable vertical accretion on the main channel and a considerable reduction of the fine sediment supply to the alluvial floodplain. The increasing concentration of relatively plastic fine sediments on the bottom of the main channel during the 20th century explains the higher compressibility of these units, especially in the corrected channel in 1981 (ACH 1981). In this case, the sediment recruitment by embankments is especially significant.

In the areas near the river, the lowest mean subsidence rates were found in the AC (from -9.43 to $-10.45 \mathrm{~mm}$ ) and LAC (-11.18 mm for 1995-2005) units (Fig. 4).

The meanders abandoned before channelisation (AMP) have deformation values slightly lower than those for active ones or meanders isolated recently from the present thalweg $(-10.49 \mathrm{~mm}$ in 1995-2005 and $-19.69 \mathrm{~mm}$ in 2004-2008) (Fig. 4). Although they are usually located in a buffer area less than $1.5 \mathrm{~km}$ from the river course, several centuries have elapsed since their cut-offs. The course of the river near Murcia city during the Muslim period seems to be similar to the 20th century course, before its whole channelisation (Estrella Sevilla and García-Ayllón 2012). As the abandoned meanders become further from the current thalweg, the mean accumulated subsidence decreases. In fact, the older abandoned meanders (OAM) located in the southern part of the valley, 3-4 km from the river, had the highest degree of stability of these units, exhibiting cumulative displacements of less than $4.5 \mathrm{~mm}$ in 1995-2005 and -13.5 mm in 2004-2008 (Fig. 4).

Finally, we should mention three marginal units around the valley bottom, which have the highest stability rates: i) the distributary channels in the area of affluence from the Guadalentín River to the Segura River (DCH-G); ii) the fluvial terraces of the Segura River surrounding the Alcantarilla town (T); and iii) the alluvial fans that flank the VMSR (AF). In the case of the DCH-G unit the low number of PSs present $\left(29 \mathrm{PSs} / \mathrm{km}^{2}\right)$ reduces the reliability of the rates obtained. However, for the fluvial terraces (T) and the alluvial fans (AF), the density of PSs is much higher (486 and $101 \mathrm{PSs} / \mathrm{km}^{2}$, respectively, in 1995-2005) and this considerably increases the statistical reliability of the results. In both cases and for analysis periods, the mean accumulated displacement was less than $-6 \mathrm{~mm}$, while the standard deviation values are quite low compared to those estimated for the remaining units ( $\sigma$ between 4.6 and 7.2 for the period 2004-2008).

\section{Lateral acretion zones (LAC)}

The LAC show a sedimentary series with grain-decreasing tendency (Fig. 5, G-179 and G-197), composed of the following lithofacies, from wall to top: (a) sands with crossed trough stratification; (b) sandy silt ripple marks and small-scale cross-stratification; and (c) laminated silty clays. This sequence type has lower ground compressibility than recently active channels (now abandoned meanders). Nonetheless, drastic drops in the 
317 groundwater level during long droughts (e.g. period 2005-2007) have resulted in non-negligible subsidence rates

$318(>4 \mathrm{~mm} /$ year $)$ for LAC.

319

320

Artificial cutoff by channelisation in 1981 (AC)

321

322

Abandoned meanders have recently appeared due to the artificial cut-offs caused by the channelisation of the Lower Segura in 1981. Since this date, the segregated meanders have stopped being active, but they have not received any deposits due to the lack of overflow events in the channelled river reach. As a result, these channels do not have the grain-decreasing sequence (fining upwards) with an upper clay level, observed in natural abandoned meanders. On the contrary, they were filled by slightly compacted made-man deposits consisting mainly of silts and sandy-silts. Their moderate compressibility led to low subsidence rates for both analysis periods (less than $2 \mathrm{~mm} /$ year).

329

\section{Abandoned meanders before channelisation (AMP)}

331

332

The sediment loads that currently feed these reaches are mainly made up of fine sand, silt and clay, with gravels and pebbles being very scarce or non-existent. The recent evolution of the Lower Segura on its course through the Vega Media makes it possible to distinguish 11 traces of abandoned meanders, which can be grouped into two types (Type I and Type II). Type I is composed of meanders abandoned due to dominant neck cut-off processes with minor chute cut-off phases (AM 0, 3, 6 and 8). However, Type II meanders include abandoned meanders with different curvature radii and wavelengths with long point bars and very homogeneous channel fillings (AM 4, 5, 7, 9 and 10). These are filling deposits caused by chute cut-off phenomena, associated with the progressive shortening of their length, the rehabilitation of old subsidiary channels or the excavation of local depressions existing between the cordons of the meander. Consequently, the filling series of Type I show an upper stretch of well developed vertical silt-clay accretion, on top of another stretch that is less thick in silts, sands or gravels, corresponding to the abandonment phase (Fig. 5, G-84 and G-91). The relatively young age of some of these fillings (i.e. AM 6 and 8) confers on them a very low degree of compaction. Furthermore, the upper clay part of the Type II series usually has a lower thickness than the underlain silty-sand sediments which originated throughout the meander abandonment stage. For these cases, the young age and the compaction degree of the deposits is quite variable,

347 depending on the channel displacement or migration phase.

348 Usually these abandoned meanders (AMP) show high subsidence values (Fig. 6). They had maximum displacement values of -33.6 and $-30.6 \mathrm{~mm}$ for the 1995-2005 and 2004-2008 periods, respectively. For all cases, a silty-clay formation with a thickness greater than $10 \mathrm{~m}$, which eventually could include interbedded sand layers, is present. The percentage of the mentioned sand layers could explain the differing degrees of 
353 affected the area, mainly during the second period analysed (2004-2008). Meanders 0 and 8 (AMP Type I), 354 constituted by thick low plasticity clay and silt layers, exhibited the highest mean displacements for both periods. 355 However, meanders nr. 7 and 10 (AMP Type II), which show several levels of lenticular interbedded sand, are 356 the most stable, exhibiting displacements of up to $-8.3 \mathrm{~mm}$. The comparison of the displacement values for both 357 periods derived from InSAR clearly shows the influence of the temporal fluctuation of the piezometric level.

358 The CHS (2007a) and Mulas et al. (2010) documented the occurrence of a large piezometric fall in this area 359 between 2006 and 2007, due to the effects of a severe drought episode which affected the VMSR from July 2005 360 to April 2007. This fact would explain why, considering the deformational behaviour of the different 361 sedimentary bodies that constitute the meanders, most of them suffered their highest deformation during the 362 2004-2008 period rather than during 1995-2005. These increments varied from $6.2 \mathrm{~mm}$ (AM 6) to 18.1 mm (AM

363 8) (Fig. 6), and only in abandoned meanders 0 and 4 did subsidence decrease. Nevertheless it must be taken into 364 account that due to the small size of these units, sometimes only a small number of PSs are available for the 365 study of their deformational behaviour (e.g. meanders nr. 0, 2, 9 and 10 include less than 10 PSs). Note that for 366 every detected PS from the A-DInSAR analysis of the ERS \& ENVISAT satellite images, displacement 367 measurements represent the deformation behaviour of those elements (buildings, urban structures, geomorphological units, etc.) included within a $4 \mathrm{~m} \mathrm{x} 20 \mathrm{~m}$ area of the ground surface. Therefore the presence of few PS points within several meander units could lead to a bias in the interpretation.

\section{Non-active floodplain and spilling zones (FP-SP)}

372

The sediment data available for the floods occurring during the period 1879-1956 have allowed us to differentiate between two subunits: (a) the non-active floodplain (FP) composed of fine materials (silt and clay) in the parts which are furthest from the channel (Fig. 5, G-388 and G-396) and somewhat coarse material (sands) in the natural dykes that border its banks (Fig. 5, G-239) (the latter being characterised by ripple type sedimentary structures and horizontal lamination); and (b) spilling zones (SP) or crevasse splays fed by sandysilt and sandy sediment supplies (Fig. 5, G-402 and 406) following a breakage of natural levees over the concave banks during flooding events. In general both alluvial subunits (FP and SP) showed behaviour similar to that of the lateral accretion zones (LAC), with mean deformation values of -1.5 to $-4 \mathrm{~mm} / \mathrm{year}$. The mean

Fluvial Terraces (T, G-T and SG-T)

The geomorphological interpretation of these terrace levels is somewhat more complex due to the large number of factors that have affected their genesis. In some cases, the normal ranking of fluvial surfaces has been greatly altered by recent tectonic manifestations or by anthropic action itself (agricultural terraces). The origin of the 
389

390

391

392

393

394

395

396

397

398

399

400

401

402

403

404

405

406

407

408

409

410

411

412

413

414

415

416

417

418

419

420

421

422

423

424

fluctuations (López-Bermúdez and Thornes 1986; Silva et al. 2008). However, a large part of this alluvial system has always been affected by intense neotectonic activity (Silva et al. 2004). In fact, the T1 and T2 levels contain deformations and, locally, they have significant steps which have favoured their alluvial filling.

The T1 level $(21 \mathrm{~m})$, considered as the oldest, is supported by an erosive base on a conglomeratic Miocene substrate (Fig. 7a), being visible at a thickness of 3 to $4 \mathrm{~m}$. Its basal deposits are strongly cemented by carbonates of a synsedimentary and phreatic origin. In general, the $\mathrm{Gm}$ sedimentary facies predominate and are characterised by an extended grain size distribution $\left(\sigma=6.2\right.$ to 8.0), with median values $\left(\mathrm{D}_{50}\right)$ of about $1.5 \mathrm{~cm}$ and an $84^{\text {th }}$ percentile $\left(\mathrm{D}_{84}\right)$ between 6.6 and $7 \mathrm{~cm}$. Only occasionally do isolated blocks with sizes of 23 to 27 cm appear (Table 4).

Level T2 is made up mainly of type Fm and Gp sedimentary facies (Fig.s 7b, $8 b$ and $8 c$ ). The first of these are represented by silt and clay deposits without any apparent structure, with a thickness varying from a few millimetres (with an $\mathrm{Fl}$ appearance) to several dozen centimetres (AVT $=0.8-2.2 \mathrm{~m}$ ). The lower limit of these layers sometimes takes the shape of other underlying primary structures (i.e. bedforms), such as ripples and alluvial bars. Stratified with Fm are Gt lithofacies, made up of grain sizes which are slightly lower than those of $\mathrm{Gm}$ in $\mathrm{T} 1\left(\mathrm{D}_{50}=0.9\right.$ to $1.3 \mathrm{~cm} ; \mathrm{D}_{84}=5.5$ to $6 \mathrm{~cm}$; $\mathrm{LGS}=11.7$ to $\left.14.0 \mathrm{~cm}\right)$ (Table 4). In this case, these are detritic deposits with a concave base (broad, shallow, scoop-shaped), decreasing grain tendency and poor classification $(\sigma=6.5$ to 8.2$)$.

The T3 terrace (14 m) has a sedimentary series dominated by fine material with Fr, Fm, Sh and St facies which are not cemented (Fig. 7c). The scarce compaction of the sediments and their lower topographical position make them relatively young. In G-T1, Gm facies predominate, integrated in this case by badly-classified deposits of massive angular clasts with a grain-supported texture ( $\sigma=5.7$ to 7.4 ) (Table 4). Finally, the SG-T3 formation is very similar to the T3 level; it is very common to find the sequences with total domination of the Fm facies and with interbedding of thin sandy layers (St).

According to these lithoestratigraphic features, the fluvial terraces show a stable behaviour (Fig. 9) in terms of the A-DInSAR measurements for the periods analysed (i.e. average cumulative subsidence of less than $-6 \mathrm{~mm}$ ), except for unit SG-T3 - that exhibited an average cumulative subsidence of $-8.6 \mathrm{~mm}$ between 2004 and 2008 . This unit has the highest silt and clay content $(70 \%)$ and greatest thickness (1.4-3.2 $\mathrm{m}$ ) (Table 4); in consequence, a higher compressibility is expected. Within this group, the oldest terraces with the highest level of cementation (G-T1, T1 and T2) are the most stable units.

\section{Alluvial fans (AF, GAF and AFG)}

AF subunits. These units show a clear evolution from debris-flow to sheet-flow dominated fans, a tendency that seems to be quite common in other alluvial systems in southeast Spain (Harvey 1984, 1990, Viseras et al. 2003). The aggradational sequences of these fans show a net dominance of the Gm (Gmm and Gmg), Gt, Sm, St and Sh facies, locally cemented in the lower stretch of the series (Fig. 10). It is possible to see a progressive grain- 
425 decreasing tendency from the basal conglomerates to the silt and sandy layers with small clasts that crown the formation. On the surface there are signs of an ancient limy crust, currently broken by anthropic action.

427

GAF Subunit. The following recognized lithofacies are found in this subunit from top to bottom: 1) silts and fine sands, arranged in horizontal layers, which become silty clay material in the distal zone (with a thickness of 1.5 to $2 \mathrm{~m}$ ); 2) Fl combined with Sh (laminated sands) and St (with a thickness of 2-3.5 m) (Fig. 10), suggesting high flow stages and partial exoreic drainage from the Librilla and Algeciras ephemeral channels to the Guadalentín-Segura Rivers (unit 4 in the Lower Guadalentín, $3885 \pm 60$ BP); 3) Fm and Fl (massive and laminated silty clays) with interbedded fine sands (with a maximum thickness of 2-2.5 m), providing evidence of a low energy alluvial distal plain environment (unit 3 in the Lower Guadalentín -Calmel-Avila 2002-, dated from $6340 \pm 60 \mathrm{BP}$ to $4305 \pm 55 \mathrm{BP}$ - Silva et al. 2008-).

436

AFG subunits. The channels crossing these alluvial fans lose their craggy cross-section in the middle and lower reaches, leading to laminar sheet flows with a large lateral extension and with hardly any energy. In this way, alluvial fans are joined together by a flat or slightly wavy surface. They are mainly made up of silty-sandy deposits, which are interspersed with clay layers, and - to a lesser degree - conglomerate facies. The coarsest detritic materials adopt a tabular geometry in the upper areas and a channel-like cross-section with a lenticular structure in the middle parts.

443 The spatial distribution of the PSs used for the analysis of the cumulative displacement distribution in the alluvial fans (AF) and abandoned meanders before channelisation (AMP) is shown in Fig. 11.

The alluvial fans exhibited a generally stable behaviour (Fig. 12), with a peak average cumulative subsidence of $-9.8 \mathrm{~mm}$ for the GAF unit during the period 2004-2008. Note that, as previously reported, AF alluvial fans (AF1, $\mathrm{AF} 2)$ and $\mathrm{AFG}$ (AFG1 and AFG2) are partially cemented and hence less deformation is expected. This can be appreciated in Fig. 10, where the AF units show average cumulative subsidence values of less than $6 \mathrm{~mm}$ for both periods.

Within this group, the greatest subsidence was measured in the GAF unit. This is due to the fact that this unit is composed of fine-grained sediments retrieved from the final part of the Guadalentín River drainage system. Note that, unlike the AF units, GAF, particularly its distal area, is formed by fine, non-compacted materials deposited in the alluvial plain under subcritical hydraulic regime conditions.

454

\section{Subsidence pattern: significance and contextualisation}

In general, there is an intimate connection between lithostratigraphy, faults, ground-water withdrawal and subsidence. As is well known, the magnitude of the subsidence induced by water withdrawal essentially depends on the deformability of the soil, its thickness and the magnitude and duration of the water level fall (Tomás et al. 
461 period), land subsidence mainly depends on the thickness and compressibility of the different sedimentary units.

462 Consequently, a difference in the subsidence behaviour is expected for different lithostratigraphic units that are 463 more or less cemented. Otherwise, fault activity can overlap water extraction induced subsidence. However,

464

465

466

467

468

469

470

471

472

473

474

475

476

477

478

479

480

481

482

483

484

485

486

487

488

489

490

491

492

493

494

495

496 tectonic subsidence usually affects wide areas constituting an additional constant subsidence or uplift rate which can be easily subtracted from the general subsidence trend. In the VMSR, tectonic subsidence is several orders of magnitude lower than the subsidence induced by water withdrawal and consequently, can be neglected in this study. The following subsections show the different deformational patterns and the effect of drought periods on land subsidence induced by water withdrawal.

\section{A differential subsidence pattern associated with active faults and alluvial forms}

At present, there are many descriptions of subsidence patterns associated with faults. Examples of these are the patterns described by Amelung et al. (1999) for Las Vegas Valley, using InSAR-derived surface-deformation maps, and by Galloway et al. (2000) for San Jose near to the Silver Creek fault, from time-sequential interferograms. Also, stratigraphy studies have focused on this type of patterns. Such is the case of the chronostratigraphic study performed by Cinti et al. (2008) in the Grottaperfetta alluvial valley, where lateral variations in the elevation of different stratigraphic boundaries were associated with a fault system. In other alluvial valleys, like that of Mashhad, the subsidence area is structurally controlled by the trends of Quaternary faults causing very high subsidence rates in the softest fine-grained (up to $15 \mathrm{~cm} \mathrm{yr}^{-1}$ between 2003 and 2005 from InSAR data) (Motagh et al. 2007).

The VMSR is part of a broad trough whose evolution and stratigraphy have been clearly influenced by tectonics at the regional scale. The presence of active regional faults in the northern and southern limits of the VMSR causes a tectonic subsidence that affects the entire valley. In addition, differing sediment ages and lithostratigraphic differences between adjacent alluvial forms lead to variable rates of ground elevation, suggesting a differential subsidence pattern. The oldest terraces and alluvial fans currently have high stability and low compressibility, while the alluvial forms adjacent to the river are part of the historical pattern of regional subsidence of the valley floor.

The dominance of massive and bedded gravels in the older alluvial fans (subunit AF) makes them currently one of the most stable landforms of the study area, with vertical displacements between -5 and $+5 \mathrm{~mm} / \mathrm{yr}$. These low rates are consistent with those recorded by InSAR for the other gravel fans (Baer et al. 2002). However, the analysis of the stratigraphic architecture and aggradational sequence sets in AF located in the southeast of the VMSR reveals the long-term existence of a near-surface subsidence pattern associated with the Neogene fault system. This strata stacking pattern was described previously by Viseras et al. (2003) in the lower Segura basin. A similar near-subsidence pattern was also proposed by Bull (1964) in western Fresno County, for alluvial-fan deposits characterised by a variety of textural and structural features (graded bedding, laminations, crossbedding and imbricated larger fragments). 
497 Changes in fluvial terrace elevations are often also related to the presence of active faults. Analysis of the 498 deformation of river terraces has long been a tool for neotectonic studies, particularly those that aim to discover the rates and patterns of deformation and rock uplift associated with active faulting processes. Thereby, HubertFerrari et al. (2002) suggested ground deformation rates of $18.4 \pm 2.6 \mathrm{~mm} / \mathrm{yr}$ and $17.8 \pm 5.3 \mathrm{~mm} / \mathrm{yr}$ for 10,00012,000 yr old and 1600-4000 yr old stream terrace offsets, respectively, along the northern Anatolian Fault, and

502 Gray (2007) estimated an average uplift rate of $11.3 \pm 3.6 \mathrm{~mm} / \mathrm{yr}$ for the last $1400 \mathrm{cal}$. yr B.P. in deformed 503 Holocene strath terraces of the Bieh River, eastern Taiwan. In the VMSR, the stratigraphic discontinuity 504 observed in the upper terrace levels (GT1, T1 and T2), of the Late Pleistocene and Holocene, does not reflect 505 uplift processes, but rather a tectonic subsidence pattern, clearly influenced by the Alhama fault. At present, the InSAR-measured displacement on these terraces is negligible, with subsidence rates of about $1 \mathrm{~mm} / \mathrm{yr}$ or less during the period 1995-2008 - consistent with the historical pattern of elevation stability of the oldest alluvial forms in this study area.

509 The most variable deformation rates along the VMSR were observed in the flat valley-floor (from $-5 \mathrm{~mm}$ to -30 $510 \mathrm{~mm}$ for the period 2004-2008). These data are consistent with extensometer measurements obtained in the 511 Murcia plain between February 2001 and October 2008 (accumulated deformation from -10,8 mm to -49,1 mm) 512 (Mulas et al. 2010). The spatial variability of displacement rates in these flat areas is not due to the process of 513 tectonic subsidence, but rather to the different compressibility of their lithostratigraphic units. Young 514 sedimentary sequences, caused by the succession of various cycles of stability and meander migration over the 515 past centuries, alternate with stratigraphic stretches of fine, more consolidated materials (silts and clays) 516 deposited during historic phases of floodplain aggradation (Conesa-García 2012). Very variable subsidence 517 values have also been obtained using InSAR in various Mediterranean floodplains, such as the Emilia-Romagna 518 area, in the Po Plain ( $-2 \mathrm{~mm} / \mathrm{yr}$ to $-39 \mathrm{~mm} / \mathrm{yr}$ ) during recent decades (Amorosi et al. 2004), the flat plain of 519 southern Lombardia (displacements from -10 to $-30 \mathrm{~mm}$ for the period 1992 to 2000) (Meisina et al. 2006), the 520 Lucca floodplain (Central Italy) (about 20-30 mm during 1992-2003) (Disperati et al. 2006) and the Campanian 521 Plain, Southern Italy (up to $-5 \mathrm{~mm} / \mathrm{yr}$ from 1995 to 2011) (Cascini et al. 2013 and Peduto et al. 2015).

522 Nevertheless, in contrast to the VMSR, in these plains there is a lower presence of fine-grained materials, 523 particularly in Emilia Romana, where the main channel-related lithofacies are massive, horizontally- or cross524 stratified gravels, the chutes or abandoned channels consist of lens-shaped sand bodies topping gravel units, and 525 in flood areas coarse-grained sediments are often abruptly overlain by tabular silty-clay deposits.

526

Subsidence related to ground-water withdrawals during drought periods

528

529

530

531

532

As it is well known, subsidence is due to the consolidation of fine-grained sediments derived from the gradual reduction of voids in the soft sediments when large amounts of groundwater are withdrawn from the aquifers. Worldwide examples confirm this correlation between variation in groundwater table level due to water withdrawal and land surface displacement, for example, in Las Vegas Valley, Nevada (Hoffmann et al. 2001), Antelope Valley and Santa Clara Valley, California (Galloway et al. 1998) and theToluca Valley, Mexico 
533 (Calderheadet al. 2011). In the VMSR, decreases in the piezometric level are mainly due to increases in water 534 extraction. These water extractions have increased considerably since the 1970s due to the growing water 535 demand for domestic, agricultural and industrial uses. Note that in 2011 the study area had a population density 536 higher than 300 inhabitants per square kilometre and the population of the region has almost doubled since the 537 1960s (INE 2014). In order to attend this water demand, more than 600 domestic and agricultural wells which 538 extract water from the VMSR aquifer are estimated to exist in this valley (CHS 2007b; Tomás et al. 2011). Of 539 these wells, 24 were called "drought wells" because they maintain the water supply during drought periods. In 540 this context, the effects of drought on groundwater levels and associated subsidence in the VMSR are very 541 significant. During the periods 1993-1995 and 2005-2008, severe drought episodes caused the piezometric level 542 to fall by up to 8 and $10 \mathrm{~m}$, respectively (Tomás 2009), as well as producing displacements of the ground surface 543 (i.e. settlement due to the consolidation of underlying layers), which strongly reflected the response of the 544 different underlying alluvial units. Consequently, important damage to buildings and other structures, with an 545 estimated cost of 50 million euros and a significant social impact, was reported by Martínez et al. (2004) for the 546 first drought period (1993-1995). For the second, more recent drought episode, some minor new damage was 547 also described (Herrera et al. 2010; Bru et al. 2013). Under such conditions (general groundwater withdrawals, 548 associated with severe drought episodes), A-DInSAR has proved to be a suitable complementary instrument for 549 the identification in the VMSR of different deformation patterns, associated with differing alluvial landforms.

\section{Conclusions}

551

552 The results from this analysis reveal slightly different deformation behaviours of the different alluvial units: (1) 553 Abandoned meanders near to the river are the youngest units and, as a consequence, show the highest subsidence 554 of the study area. However due to the small size of these units few PS points have been detected in several 555 meanders and hence the interpretation could be biased; (2) Fluvial terraces show a stable behaviour - except for 556 unit SG-T3, which is the youngest and has the highest silt and clay content and the greatest thickness; (3) 557 Alluvial fans exhibit, as expected, a generally stable behaviour, which is controlled by the cementation level. On 558 the other hand, the GAF unit is formed by fine, non-compacted materials deposited on the alluvial plain under 559 subcritical hydraulic regime conditions, where Fl facies are dominant. Consequently, highly deformable areas 560 are controlled mainly by the non-active floodplain and recently abandoned meanders (active channels during the $56120^{\text {th }}$ century), and moderate deformation affects the lower terraces close to Alcantarilla town and older meanders 562 located in the confluence of the Guadalentín and Segura Rivers (south of Murcia city). Finally, non563 deformational alluvial units are represented by consolidated alluvial fans and upper fluvial terraces.

564 Taking into account the limitations involved in this analysis, mainly related to the small size of certain alluvial 565 units and the resolution provided by the A-DInSAR processing of ERS \& ENVISAT SAR images, high 566 resolution images will be used in future work. The future exploitation of TerraSAR-X images with an improved 567 spatial resolution of $1.6 \mathrm{~m}$ by $1.9 \mathrm{~m}$ in the Strip map mode could improve the geomorphological analysis of 
568

569

570

571

572

573

574

575

576

577

578

579

580

581

582

583

584

585

586

587

588

589

590

591

592

593

594

595

596

597

598

599

600

601

602

603

604

605

606

607

608

609

610

611

612

smaller alluvial forms (e.g. the abandoned urbanized meanders) although the vegetated areas or farmlands can be affected by decorrelation, as the shorter wavelength can be backscattered more easily from smaller particles.

Acknowledgements

This work has been supported by project 15224/PI/10 (Dynamics and recent morphological adjustments in the Lower Segura River, Middle Valley) from the Fundación SENECA of the Regional Agency of Science, Murcia, Spain, and the Spanish Ministry of Economy and Competitiveness (MINECO) and EU FEDER, under Projects

TEC2011-28201-C02-02, TIN2014-55413-C2-2-P, ESP2013-47780-C2-2-R and PRX14/00100. The European

Space Agency's (ESA) Terrafirma project has provided all the SAR data processed with the SPN technique and the processing itself was funded by this project.

Authors:

Carmelo Conesa-García, Departamento de Geografía Física, Universidad de Murcia. Campus de la Merced, s/n, E-30001 Murcia, Spain. E-mail: cconesa@um.es (corresponding author),

Roberto Tomás, Departamento de Ingeniería Civil, Escuela Politécnica Superior, Universidad de Alicante, P.O. Box 99, E-03080 Alicante, Spain. E-mail: roberto.tomas@ua.es.

Gerardo Herrera, Unidad Asociada de Investigación IGME-UA de Movimientos del Terreno mediante Interferometría Radar (UNIRAD). Geohazards Remote Sensing Laboratory, Instituto Geológico y Minero de España, Ríos Rosas 23, E-28003 Madrid, Spain. E-mail: g.herrera@igme.es.

Francisco López-Bermúdez, Departamento de Geografía Física, Universidad de Murcia. Campus de la Merced, s/n, E-30001 Murcia, Spain. E-mail: lopber@um.es.

Miguel Cano, Departamento de Ingeniería Civil, Escuela Politécnica Superior, Universidad de Alicante, P.O. Box 99, E-03080 Alicante, Spain. E-mail: miguel.cano@ua.es.

Francisca Navarro Hervás, Departamento de Geografía Física, Universidad de Murcia. Campus de la Merced, s/n, E-30001 Murcia, Spain. E-mail: franaher@um.es.

Pedro Pérez-Cutillas, Centro de Edafología y Biología Aplicada del Segura, CSIC - Consejo Superior de Investigaciones Científicas, Campus Universitario de Espinardo, E-30100 Murcia, Spain. E-mail: pedrope@um.es.

\section{References}

Alfaro, P. 1995. Neotectónica en la Cuenca del bajo Segura (Sector Oriental de la Cordillera Bética). Tesis doctoral. Universidad de Alicante, Alicante.

Amelung, F., Galloway, D.L., Bell, J.W., Zebker, H.A. and Laczniak, R.J. 1999. Sensing the ups and downs of Las Vegas--InSAR reveals structural control of land subsidence and aquifer-system deformation. Geology 27, 483-486.

Amorosi, A., Cibin, U., Severi, P. and Stefani, M. 2004. Late Quaternary evolution of the Po plain from surface and subsurface data: a traverse from the Apennines to the Adriatic Sea, 32nd International Geological Congress: Florence, Italy, vol. 2, B-24.

Arnaud, A., Adam, N., Hanssen, R., Inglada, J., Duro, J., Closa, J. and Eineder, M. 2003. ASAR ERS Interferometric Phase Continuity. Geoscience and Remote Sensing Symposium, 2003. IGARSS '03. Proceedings. 2003 IEEE International, vol 2, 1133-1135. 
613 Baer, G., Schattner, U., Wachs, D., Sandwell, D., Wdowinski, S. and Frydman, S. 2002. The lowest place on

Earth is subsiding -An InSAR (interferometric synthetic aperture radar) perspective. Geological Society of America Bulletin 114, 12-23.

Bru, G., Herrera, G., Tomás, R., Duro, J., De la Vega, R. and Mulas, J. 2013. Control of deformation of buildings affected by subsidence using persistent scatterer interferometry. Structure and Infrastructure Engineering 9, 188-200.

Bull, W.B. 1964. Alluvial Fans and Near-Surf ace Subsidence in Western Fresno County California. Geological Survey Professional Paper 437-A. United States Government Printing Office, Washington.

Calderhead, A.I., Therrien, R., Rivera, A., Martel, R. and Garfias, J. 2011. Simulating pumping-induced regional land subsidence with the use of InSAR and field data in the Toluca Valley, Mexico. Advances in Water Resources 34, 83-97.

Calmel-Avila, M. 2000. Procesos hídricos holocenos en el bajo Guadalentín (Murcia, SE España). Revista Cuaternario y Geomorfología 14, 65-78.

Calmel-Avila, M. 2002. The Librilla rambla, an example of morphogenetic crisis in the Holocene (Murcia, Spain). Quaternary International 93-94, 101-108.

Cascini, L., Ferlisi, S., Peduto, D., Fornaro, G. and Manunta, M. 2007. Analysis of a subsidence phenomenon via DInSAR data and geotechnical criteria. Italian Geotechnical Journal 41, 50-67.

Cascini, L., Peduto, D., Reale, D., Arena, L., Ferlisi, S., Verde, S. and Fornaro, G. 2013. Detection and monitoring of facilities exposed to subsidence phenomena via past and current generation SAR sensors. J. Geophys. Eng. 10 (6), 064001. doi:10.1088/1742-2132/10/6/064001

CHS 2007a. Caracterización adicional de las masas de agua subterránea en riesgo de no cumplir los objetivos medioambientales en 2015. Vega media y baja del Segura. Demarcación Hidrográfica del Segura: Murcia.

CHS 2007b. Nuevas aportaciones al conocimiento hidrogeológico del entorno urbano de Murcia. Technical report, 363 pp. www.chs.es.

Cigna, F., Osmanoğlu, B., Cabral-Cano, E., Dixon, T.H., Ávila-Olivera, J.A., Garduño-Monroy, V.H., DeMets, C. and Wdowinski, S. 2012. Monitoring land subsidence and its induced geological hazard with Synthetic Aperture Radar Interferometry: A case study in Morelia, Mexico. Remote Sensing of Environment 117, 146161.

Cinti, F.R., Marra, F., Bozzano, F., Cara, F., Di Giulio, G. and Boschi, E. 2008. Chronostratigraphic study of the Grottaperfetta alluvial valley in the city of Rome (Italy): investigating possible interaction between sedimentary and tectonic processes. Annals of Geophysics 51, 849-865.

Conesa-García, C., Pérez-Cutillas, P., García-Lorenzo, R. and Martínez-Salvador, A. 2012. Cambios históricos recientes de cauces y llanuras aluviales inducidos por la acción del hombre. Nimbus, Revista de Climatología, Meteorología y Paisaje 29-30, 159-176.

Dang, V.K., Doubre, C., Weber, C., Gourmelen, N. and Masson, F. 2014. Recent land subsidence caused by the rapid urban development in the Hanoi region (Vietnam) using ALOS InSAR data. Natural Hazards Earth System Sciences 14, 657-674.

Disperati, L., Virdis, S., Feigl, K.L. and Rindinella, A. 2006. Land subsidence monitoring in the Lucca Plain (Central Italy), in: Lacoste, H, Ouwehand, L. (Eds.), Fringe 2005 Workshop, ESA SP-610, European Space Agency. 
653

654

655

656

657

658

659

660

661

662

663

664

665

666

667

668

669

670

671

672

673

674

675

676

677

678

679

680

681

682

683

684

685

686

687

688

689

690

691

Duro, J., Closa, J., Biescas, E., Crosetto, M. and Arnaud, A. 2005. High Resolution Differential Interferometry Using Time Series of ERS and ENVISAT SAR Data. Proceedings 6th Geomatic Week Conference, February 8-11, Barcelona.

Estrella-Sevilla, E. and García-Ayllón, S. 2012. La evolución urbana de la ciudad de Murcia en relación con el río Segura. Revista de Obras Públicas 159:69-82.

FUSION LIDAR/IFSAR v. 2.9. http://forsys.cfr.washington.edu/JFSP06/lidar_\& ifsartools .htm. Forest Service - Agriculture Departament United States (USDA).

Galloway, D.L. and Hoffmann, J. 2007. The application of satellite differential SAR interferometry-derived ground displacements in hydrogeology. Hydrogeol. J. 15, 133-154.

Galloway, D.L., Hudnu, K.W., Ingebritsen, S.E., Phillips, S.P., Peltzer, G., Rogez, F. and Rosen, P.A. 1998. Detection of aquifer system compaction and land subsidence using interferometric synthetic aperture radar, Antelope Valley, Mojave Desert, California. Water Resources Research 34, 2573-2585.

Galloway, D.L., Jones, D.R. and Ingebritsen, S.E. 2000. Measuring Land Subsidence from Space. Report April 2000. US Department of the Interior US Geological Survey.

Goy, J.L., Zazo, C., Somoza, L. and Dabrio, C.J. 1989. The neotectonic behaviour of the Lower Segura River Basin during the Quaternary Palaogeographical meaning of the "Conglomerates of the Segura". Bulletin of the INQUA Neotectonics Commission 12, 14-17.

Gray, B.T. 2007. Late Holocene uplift of the Chihshang segment of the longitudinal valley fault at Fuli, Eastern Taiwan, Thesis, August 2007, Central Washington University.

Harvey, A.M. 1984. Aggradation and dissection sequences on Spanish alluvial fans: influence on morphological development. Catena 11, 289-304.

Harvey, A.M. 1990. Factors influencing Quaternary alluvial fan development in southeast Spain, in: Rachocki, A.H, Church, M. (Eds), Alluvial Fans: A Field Approach. J. Wiley, New York, pp 247-269.

Heleno, S.I.N., Oliveira, L.G.S., Henriques, M.J., Falcão, A.P., Lima, J.N.P., Cooksley, G., Ferretti, A., Fonseca, A.M., Lobo-Ferreira, J.P. and Fonseca, J.F.B. 2011. Persistent scatterers interferometry detects and measures ground subsidence in Lisbon. Remote Sens. Environ. 115, 2152-2167.

Herrera, G., Fernández, J.A., Tomás, R., Cooksley, G. and Mulas, J. 2009a. Advanced interpretation of subsidence in Murcia (SE Spain) using A-DInSAR data-modelling and validation. Natural Hazards and Earth System Sciences 9, 647-661.

Herrera, G., Tomás, R., López-Sánchez, J.M., Delgado, J., Vicente, F., Mulas, J., Cooksley, G., Sanchez, M., Duro, J., Arnaud, A., Blanco, P., Duque, S., Mallorqui, J.J., De la Vega-Panizo, R. and Monserrat, O. 2009 b. Validation and comparison of Advanced Differential Interferometry Techniques: Murcia metropolitan area case study. ISPRS Journal of Photogrammetry and Remote Sensing 64, 501-512.

Herrera, G., Tomás, R., Monells, D., Centolanza, G., Mallorquí, J.J., Vicente, F., Navarro, V.D., López-Sánchez, J.M., Sanabria, M., Cano, M. and Mulas, J. 2010. Analysis of subsidence using TerraSAR-X data: Murcia case study. Engineering Geology 116, 284-295.

Hoffmann, J., Galloway, D.L. and Zebker, H.A. 2003. Inverse modeling of interbed storage parameters using land subsidence observations, Antelope Valley, California. Water Resources Research 39, 1031 doi: 10.1029/2001WR001252. 
692

693

694

695

696

697

698

699

700

701

702

703

704

705

706

707

708

709

710

711

712

713

714

715

716

717

718

719

720

721

722

723

724

725

726

727

728

729

730

Hoffmann, J., Zebker, H.A., Galloway, D.L. and Amelung, F. 2001. Seasonal subsidence and rebound in Las Vegas Valley, Nevada, observed by synthetic aperture radar interferometry. Water Resources Research 37 , 1551-1566.

Hubert-Ferrari, A., Armijo, R., King, G., Meyer, B. and Barka, A. 2002. Morphology, displacement, and slip rates along the northern Anatolian Fault, Turkey. J. Geophys. Res. 107, 22-35, doi: 10.1029/2001JB000393.

INE 2014 Instituto Nacional de Estadística. Estimaciones de población, censos y cifras oficiales de población. http://www.ine.es/inebmenu/mnu_cifraspob.htm.

Karila, K., Karjalainen, M. and Hyyppä, J. 2005. Urban Land Subsidence Studies in Finland Using Synthetic Aperture Radar Images and Coherent Targets. Photogramm. J. Finland 19, 43-53.

López-Bermúdez, F. and Thornes, J.B. 1986. Palaeoclimatic, palaeoenvironmental and anthropic interactions in SE Spanish Holocene prehistory, in: Estudios sobre geomorfología del Sur de España, Universidad de Murcia, pp 59-66.

Martínez, M., Mulas, J., Herrera, G. and Aragón, R. 2004. Efectos de una subsidencia moderada por extracción de agua subterránea en Murcia, España, in: Proc. XXXIII Congress of IAH-ALHSUD, Zacatecas, Mexico. Conference on Groundwater Flow Understanding from Local to Regional Scales, CD ROM.

Meisina, C., Zucca, F., Fossati, D., Ceriani, M. and Allievi, J. 2006. PS InSAR Integrated with Geotechnical GIS: Some Examples from Southern Lombardia. Geodetic Deformation Monitoring. Geophysical to Engineering Roles International Association of Geodesy Symposia 131, 65-72.

Meristemum Red GNSS 2013. http://gps.medioambiente.carm.es/. Dirección General de Medio Ambiente, Consejería de Presidencia de la Comunidad Autónoma de Murcia.

Miall, A.D. 1996. The Geology of Fluvial Deposits: Sedimentary Facies, Basin Analysis and Petroleum Geology. Springer Verlag, Inc.: Heidelberg.

Montenat, C. 1977. Les basins néogenes et quaternaires du Levant d' Alicante à Murcie (Cordilleres bétiques orientales, Espagne). Stratigraphie, paleontology et evolution dynamique. Documents des Laboratoires de Géologie de Lyon, 63, 1-345.

Motagh, M., Djamour, Y., Walter, T.R., Wetzel, H.U., Zschau, J. and Arabi, S. 2007. Land subsidence in Mashhad Valley, northeast Iran: results from InSAR, levelling and GPS. Geophys. J. Int. 168, 518-526.

Mulas, J., Aragón, R. and Clemente, A.A. 2010. La subsidencia del terreno en la ciudad y área metropolitana de Murcia. Instituto Geológico y Minero de España, Madrid.

Mulas, J., Aragón, R., Martínez, M., Lambán, J., García-Arostegui, J.L., Fernández-Grillo, A.I., Hornero, J., Rodríguez, J. and Rodríguez, J.M. 2003. Geotechnical and hydrological analysis of land subsidence in Murcia (Spain), in: Proceedings $1^{a}$ International Conference on Groundwater in Geological Engineering, 2226 September: Bled, Slovenia; vol. 50, 249-252.

Peduto, D., Cascini, L., Arena, L., Ferlisi, S., Fornaro, G. and Reale D. 2015. A general framework and related procedures for multiscale analyses of DInSAR data in subsiding urban areas, ISPRS Journal of Photogrammetry and Remote Sensing, Volume 105, July 2015, Pages 186-210, ISSN 0924-2716, http://dx.doi.org/10.1016/j.isprsjprs.2015.04.001

PNOA 2009. http:/www.01.ign.es/PNOA/vuelo_lidar.html. Centro Nacional de Información Geográfica (CNIG), Instituto Geográfico Nacional, Ministerio de Fomento. 
731

732

733

734

735

736

737

738

739

740

741

742

743

744

745

746

747

748

749

750

751

752

753

754

755

756

757

758

759

760

761

762

763

764

765

766

767

768

Raspini, F., Cigna, F. and Moretti, S. 2012. Multi-temporal mapping of land subsidence at basin scale exploiting Persistent Scatterer Interferometry: case study of GioiaTauro plain (Italy). Journal of Maps 8, 514-524.

Raspini, F., Loupasakis, C., Rozos, D., Adam, N. and Moretti, S. 2014. Ground subsidence phenomena in the Delta municipality region (Northern Greece): Geotechnical modeling and validation with Persistent Scatterer Interferometry. International Journal of Applied Earth Observation and Geoinformation 28, 78-89.

Rodríguez-Estrella, T., Hernández-Henrile, J.L. and Ibargüen, J. 1999. Neotectónica y tectónica activa en la depresión plio-cuaternaria del Segura (Murcia-Orihuela). 1er. Congreso Nacional de Ingeniería Sísmica: Murcia; vol. I, pp 53-63.

Rodríguez-Jurado, J., Martínez-Corbella, M., Mulas, J. and Rodríguez-Ortiz, J.M. 2000. Establecimiento de un modelo geológico para el estudio de la subsidencia por rebajamiento del nivel freático. Geotemas 1, 155-158.

Sanabria, M.P., Guardiola-Albert, C., Tomás, R., Herrera, G., Prieto, A., Sánchez, H. and Tessitore, S. 2014. Subsidence activity maps derived from DInSAR data: Orihuela case study. Natural Hazards and Earth System Science 14, 1341-1360.

Silva, P.G., Alfaro, P., Masana, E., Martínez Díaz, J.J. and Bardaji, T. 2004. Active tectonics in the Mediterranean sector of the Iberian Peninsula (East Spain). 32nd International Geological Congress: Florence, Italy, pp 20-28.

Silva, P.G., Calmel-Avila, M., Bardaji, T., Goy, J.L. and Zazo, C. 2008. Transition from alluvial to fluvial systems in the Guadalentín Depression (SE Spain) during the Holocene. Lorca Fan versus Guadalentín River. Geomorphology 100, 144-153.

Silva, P.G., Harvey, A.M., Zazo, C. and Goy, J.L. 1992. Geomorphology, depositional style and morphometric relationships of Quaternary alluvial fans in the Guadalentín Depression (Murcia, Southeast Spain). Zeitschrift für Geomorphologie N.F. 36, 325-341.

Soria, J., Alfaro, P., Fernández, J. and Viseras, C. 2001. Quantitative subsidence-uplift analysis of the Bajo Segura Basin (eastern Betic Cordillera, Spain): tectonic control on the stratigraphic architecture. Sedimentary Geology 140, 271-289.

Sousa, J.J. and Bastos, L. 2013. Multi-temporal SAR interferometry reveals acceleration of bridge sinking before collapse. Natural Hazards and Earth System Sciences 13, 659-667, doi: 10.5194/nhess-13-659-2013.

Stramondo, S., Bozzano, F., Marra, F., Wegmuller, U., Cinti, F.R., Moro, M. and Saroli, M. 2008. Subsidence induced by urbanization in the city of Rome detected by advanced InSAR technique and geotechnical investigations. Remote Sens. Environ.112, 3160-3172.

Tapete, D., Fanti, R., Cecchi, R., Petrangeli, P. and Casagli, N. 2012. Satellite radar interferometry for monitoring and early-stage warning of structural instability in archaeological sites. J. Geophys. Engin. 9, 1025.

Tomás, R. 2009. Estudio de la subsidencia de la ciudad de Murcia mediante Interferometría SAR diferencial avanzada, $\mathrm{PhD}$ Thesis. Universidad de Alicante: Alicante.

Tomás, R., Herrera, G., Cooksley, G. and Mulas, J. 2011. Persistent Scatterer Interferometry subsidence data exploitation using spatial tools: The Vega Media of the Segura River Basin case study. Journal of Hydrology 400, 411-428. 
769

770

771

772

773

774

775

776

777

778

779

780

781

782

783

784

785

786

787

788

789

790

791

792

793

794

795

796

797

798

799

800

801

802

803

804

805

806

Tomás, R., Herrera, G., Delgado, J., López-Sánchez, J.M., Mallorquí, J.J. and Mulas, J. 2010. A ground subsidence study based on DInSAR data: Calibration of soil parameters and subsidence prediction in Murcia City (Spain). Engineering Geology 111, 19-30.

Tomás, R., Márquez, Y., López-Sánchez, J.M, Delgado, J., Blanco, P., Mallorquí, J.J., Martínez, M., Herrera, G. and Mulas, J. 2005. Mapping ground subsidence induced by aquifer overexploitation using advanced Differential SAR Interferometry: Vega Media of the Segura River (SE Spain) case study. Remote Sensing of Environment 98, 269-283.

Tomás, R., Romero, R., Mulas, J., Marturià, J.J., Mallorquí, J.J., López-Sánchez, J.M., Herrera, G., Gutiérrez, F., González, P.J., Fernández, J., Duque, S., Concha-Dimas, A., Cocksley, G., Castañeda, C., Carrasco, D. and Blanco, P. 2014. Radar interferometry techniques for the study of ground subsidence phenomena: a review of practical issues through cases in Spain. Environmental Earth Sciences 71, 163-181.

Vilardo, G., Ventura, G., Terranova, C., Matano, F. and Nardo, S. 2009. Ground deformation due to tectonic, hydrothermal, gravity, hydrogeological, and anthropic processes in the Campania Region (Southern Italy) from permanent scatterers synthetic aperture radar interferometry. Remote Sens. Environ. 113, 197-212.

Viseras, C., Calvache, M.L., Soria, J.M. and Fernández, J. 2003. Differential features of alluvialfans controlled by tectonic or eustatic accommodation space. Examples from the Betic Cordillera, Spain. Geomorphology $50,181-202$.

(1)

88

(

(1)


Table 1. Lithofacies and interpretations used in this study*.

\begin{tabular}{|c|c|c|}
\hline $\begin{array}{l}\text { Lithofacies } \\
\text { code }\end{array}$ & Description & Interpretation \\
\hline $\mathrm{Gmm}$ & $\begin{array}{l}\text { Massive, matrix-supported gravel to pebble } \\
\text { conglomerate, poorly sorted, disorganized, } \\
\text { unstratified }\end{array}$ & $\begin{array}{l}\text { Deposition by cohesive mud-matrix debris } \\
\text { flows }\end{array}$ \\
\hline $\mathrm{Gm}$ & Massive or crudely bedded gravel & Longitudinal bars, lag deposits, sieve deposits \\
\hline Gt & Trough cross-beds, clast supported gravel & Minor channel fills \\
\hline Gp & $\begin{array}{l}\text { Planar cross-beds gravel and/or matrix-supported } \\
\text { gravel }\end{array}$ & $\begin{array}{l}\text { Linguoid (traverse) bars. Formed as bars mi- } \\
\text { grated into deeper water. }\end{array}$ \\
\hline $\mathrm{Sm}$ & Massive sand & $\begin{array}{l}\text { Very rapid deposition from suspension or from } \\
\text { highly concentrated sandy sediment dispersions }\end{array}$ \\
\hline $\mathrm{St}$ & Trough cross-stratified sand & Dunes (lower flow regime) \\
\hline $\mathrm{Sp}$ & Planar cross-stratified sand & $\begin{array}{l}\text { Linguoid (traverse) bars. Sand waves (lower } \\
\text { flow regime) }\end{array}$ \\
\hline $\mathrm{Sr}$ & Ripple marks and small-scale cross-stratification & Ripples (lower flow regime) \\
\hline $\mathrm{Sh}$ & Horizontally stratified sand & Planar bed flow (lower and upper flow regime) \\
\hline $\mathrm{Fl}$ & Laminated or cross-laminated fine sand, silt or clay & Overbank or waning flood deposits \\
\hline $\mathrm{Fm}$ & Massive, fine sandy clay or clay & Overbank or drape deposits \\
\hline $\mathrm{Fr}$ & Massive silt and clay, sometimes bioturbed & Deposition from suspension in floodplain areas \\
\hline
\end{tabular}

*Codes and descriptions from Miall (1996). 
841 Table 2. Main characteristics of the processed data stacks of the Vega Media of the Segura River.

842

843

844

845

846

847

848

849

850

851

852

853

854

855

856

857

858

859

860

861

862

863

864

\begin{tabular}{|c|c|c|c|c|c|c|c|c|c|c|}
\hline Data stack & $\lambda$ & Orbit & $\theta$ & $\mathrm{RC}$ & GRR & Time interval & NS & $\begin{array}{l}\text { Processing } \\
\text { technique }\end{array}$ & $\begin{array}{l}\text { PS density } \\
\text { (PS/km2) }\end{array}$ & GA \\
\hline ERS1/2 & 5.6 & Desc. & 23 & 35 & 20 & $\begin{array}{l}21 / 07 / 1995- \\
22 / 10 / 2005\end{array}$ & 38 & SPN & 157 & 5 \\
\hline ERS2 ENVISAT & & & & & & $\begin{array}{l}31 / 01 / 2004- \\
20 / 12 / 2008\end{array}$ & 51 & & 102 & 3 \\
\hline
\end{tabular}

$\lambda$, wavelength $(\mathrm{cm}) ; \theta$, look angle $\left({ }^{\circ}\right)$; Desc. $=$ descending; $\mathrm{RP}=$ Repeat cycle (days); GRR $=$ Ground range resolution $(\mathrm{m}) ; \mathrm{NS}=$ Number of scene; GA = Georeference accuracy (m). 


\begin{tabular}{|c|c|c|c|c|c|c|c|c|c|c|c|c|}
\hline \multicolumn{13}{|l|}{865} \\
\hline \multicolumn{13}{|l|}{866} \\
\hline \multicolumn{13}{|l|}{867} \\
\hline \multicolumn{13}{|l|}{868} \\
\hline \multicolumn{13}{|l|}{869} \\
\hline \multicolumn{13}{|l|}{870} \\
\hline \multicolumn{13}{|l|}{871} \\
\hline \multicolumn{13}{|l|}{872} \\
\hline \multicolumn{13}{|l|}{873} \\
\hline \multicolumn{13}{|l|}{874} \\
\hline \multirow{2}{*}{\multicolumn{13}{|c|}{ Table 3 . Information about InSAR data coverage for each alluvial unit. }} \\
\hline & & & & & & & & & & & & \\
\hline & Alluvial unit & & LAC & $\mathrm{AC}$ & AMP I & FP-SP & $\mathrm{T}$ & G-T & SG-T & $\mathrm{AF}$ & GAF & AFG \\
\hline & Area $(\mathrm{km} 2)$ & & 1.81 & 0.78 & 1.68 & 4.22 & -------- & 3,63 & -------- & $----\cdot-$ & $78.89--$ & ----- \\
\hline & & PS & 223 & 513 & 839 & 1311 & 1287 & 312 & 166 & 3588 & 1808 & 2613 \\
\hline & 1995-2006 & $\mathrm{PS} / \mathrm{km}^{2}$ & 123 & 654 & 500 & 311 & 354 & 86 & 46 & 45 & 23 & 33 \\
\hline & & PS & 91 & 236 & 371 & 590 & 670 & 156 & 83 & 1616 & 1707 & 935 \\
\hline & 2004-2008 & $\mathrm{PS} / \mathrm{km}^{2}$ & 50 & 301 & 221 & 140 & 184 & 43 & 23 & 20 & 22 & 12 \\
\hline
\end{tabular}

877

878

879

880

881

882

883

884

885

886

887

888

889

890

891

892

893

894

895

896 
901

902

903

904

905

906

907

908

Table 4. Sedimentary facies and grain-size distributions in different fluvial terraces. Contraparada Area, Alcantarilla

\begin{tabular}{|c|c|c|c|c|c|c|c|c|c|c|c|c|c|}
\hline \multicolumn{9}{|c|}{ Main sedimentary facies } & \multicolumn{2}{|c|}{$\begin{array}{l}\text { Secondary } \\
\text { facies }\end{array}$} & \multicolumn{3}{|c|}{$\%$} \\
\hline $\begin{array}{l}\text { Fluvial } \\
\text { terrace }\end{array}$ & NSS & Facies & $\begin{array}{l}\text { AVT } \\
(\mathrm{m})\end{array}$ & $\begin{array}{l}\text { LGS } \\
(\mathrm{mm})\end{array}$ & $\begin{array}{c}\mathrm{D}_{84} \\
(\mathrm{~mm})\end{array}$ & $\begin{array}{c}\mathrm{D}_{50} \\
(\mathrm{~mm})\end{array}$ & $\sigma$ & DC & Facies & $\begin{array}{c}\text { AVT } \\
(\mathrm{m})\end{array}$ & PG & $\mathrm{S}$ & $\mathrm{SC}$ \\
\hline G-T1 & 2 & $\mathrm{Gm}$ & $1.0-1.6$ & $130-175$ & $47-55$ & $10-14$ & $5.8-7.4$ & M & St & $0.3-0.5$ & 24 & 49 & 27 \\
\hline $\mathrm{T} 1$ & 3 & $\mathrm{Gm}$ & $2.0-2.7$ & $230-270$ & $66-70$ & $11-17$ & $6.2-8.0$ & $\mathrm{H}^{*}$ & $\begin{array}{c}\mathrm{Gt}, \mathrm{Gp} \\
\mathrm{St}\end{array}$ & $\begin{array}{l}0.5-1.0 \\
0.4-0.8\end{array}$ & 32 & 45 & 23 \\
\hline $\mathrm{T} 2$ & 3 & $\begin{array}{l}\text { Fm } \\
\text { Gp }\end{array}$ & $\begin{array}{l}0.8-2.2 \\
0.7-1.5\end{array}$ & $\begin{array}{c}--- \\
117-140\end{array}$ & $\begin{array}{c}0.07-0.08 \\
55-60\end{array}$ & $\begin{array}{c}0.04-0.06 \\
9-13\end{array}$ & $\begin{array}{l}1.7-2.1 \\
6.5-8.2\end{array}$ & $\begin{array}{l}\mathrm{L} \\
\mathrm{M}\end{array}$ & $\begin{array}{c}\text { Fl } \\
\text { Sh, St }\end{array}$ & $\begin{array}{l}0.2-0.5 \\
0.3-0.7\end{array}$ & 20 & 36 & 44 \\
\hline $\mathrm{T} 3$ & 3 & $\begin{array}{c}\text { Fm } \\
\text { Sh, St }\end{array}$ & $\begin{array}{l}1.5-2.4 \\
0.4-0.7\end{array}$ & $\begin{array}{l}--- \\
---\end{array}$ & $\begin{array}{l}0.08-0.10 \\
0.75-1.12\end{array}$ & $\begin{array}{l}0.05-0.08 \\
0.13-0.25\end{array}$ & $\begin{array}{l}1.9-2.3 \\
2.8-3.7\end{array}$ & $\begin{array}{c}\mathrm{NC} \\
\mathrm{L}\end{array}$ & $\mathrm{Gp}, \mathrm{Gt}$ & $0.25-0.6$ & 9 & 26 & 65 \\
\hline SG-T3 & 2 & $\mathrm{Fm}$ & $1.4-3.2$ & --- & $0.09-0.11$ & $0.05-0.07$ & $1.6-2.1$ & $\mathrm{NC}$ & St & $0.4-1.0$ & 2 & 28 & 70 \\
\hline
\end{tabular}

909

910

911

912

913

914

915

916

917

918

919

920

921

922

923

924

925

926
NSS $=$ Number of sampled series; AVT = Accumulated visible thickness; LGS = Largest grain-size; DC $=$ Degree of cementation ( $H^{*}$ High at the series base; $M=$ Middle; $L=L o w ; \mathrm{NC}=$ Non-cemented); $\sigma=$ Trask's sorting index. $\mathrm{PG}=$ Pebbles and gravels; $\mathrm{S}=$ Sands, $\mathrm{SC}=$ Silts and clays. Facies classification is based on Miall (1996). 
928

929

930

931

932

933

934

935

936

937

938

939

940

941

942

943

944

945

946

947

948

949

950

951

952

953

954

955

956

957

958

959

960

961

962

963

Fig. 1. Geological setting of the Vega Baja and Media of the Segura River Basin (based on Montenat 1977).

Fig. 2. Aerial photographs showing representative alluvial units in the study area: a) artificial cut-offs (AC); b) lateral accretion zones (LAC); c) and d) abandoned meanders before channelization (AMP); e) fluvial terraces (T and G-T), f) alluvial fans (AF). Borehole codes correspond to lithology logs in Fig. 5.

Fig. 3. (Upper) Mapped geomorphological units. (Middle) Overlaying of A-DInSAR data (1995-2005) and geomorphological units. (Lower) Overlaying of A-DInSAR data (2004-2008) and alluvial units.

Fig. 4. InSAR displacements of the different mapped alluvial units for the two studied periods (1995-2006 and 2004-2008). $\sigma$ is the standard deviation and Nr. PS is the number of available Persistent Scatterers for each alluvial unit.

Fig. 5. Lithostratigraphic descriptions of boreholes drilled on alluvial units AMP, LAC y FS-SP. Source: Tomás et al. (2009). See location of boreholes in Fig. 2.

Fig. 6. InSAR displacements of the different mapped meanders (AMP) for the two studied periods (1995-2006 and 2004-2008). $\sigma$ is the standard deviation and Nr. PS is the number of available Persistent Scatterers for each geomorphological unit.

Fig. 7. (a) Base of Terrace T1: Gm facies on continental conglomerates of the upper Miocene; (b) sedimentary series in T2, from wall to ceiling: Gm, Fm, Gp, Fl, Sh; (c) T3 terrace: Fr facies in lateral contact with a Gt deposit.

Fig. 8. (a) Terrace surface T2; (b) Sedimentary series in T2 with a predominance of Gp, St and Fm facies; (c) a detail of picture (b): Gp facies inserted between Fm deposits.

Fig. 9. InSAR displacements of the different mapped river terraces. $\sigma$ is the standard deviation and Nr. PS is the number of available Persistent Scatterers for each geomorphological unit.

Fig. 10. Typical facies from basal areas of Carrascoy alluvial fans (AF) and inflow area of the Guadalentin alluvial fan in the Segura river (GAF). ChF, channel facies; IchF, interchannel facies. Note that in GAF, (a) the series are predominantly composed of silty-clays layers and in GAF (b) are mainly composed of channel and interchannel deposits. 
964 Fig. 11. Left: overlaying of InSAR data (1995-2005) with alluvial fan units (upper) and abandoned meander

965 units (lower). Right: overlaying of InSAR data (2004-2008) with alluvial fan units (upper) and abandoned me966 ander units (lower).

967

968 Fig. 12. InSAR displacements of the different mapped alluvial fans (AF) for the two studied periods (1995-2006 969 and 2004-2008). $\sigma$ is the standard deviation and Nr. PS is the number of available Persistent Scatterers for each 970 geomorphological unit. 


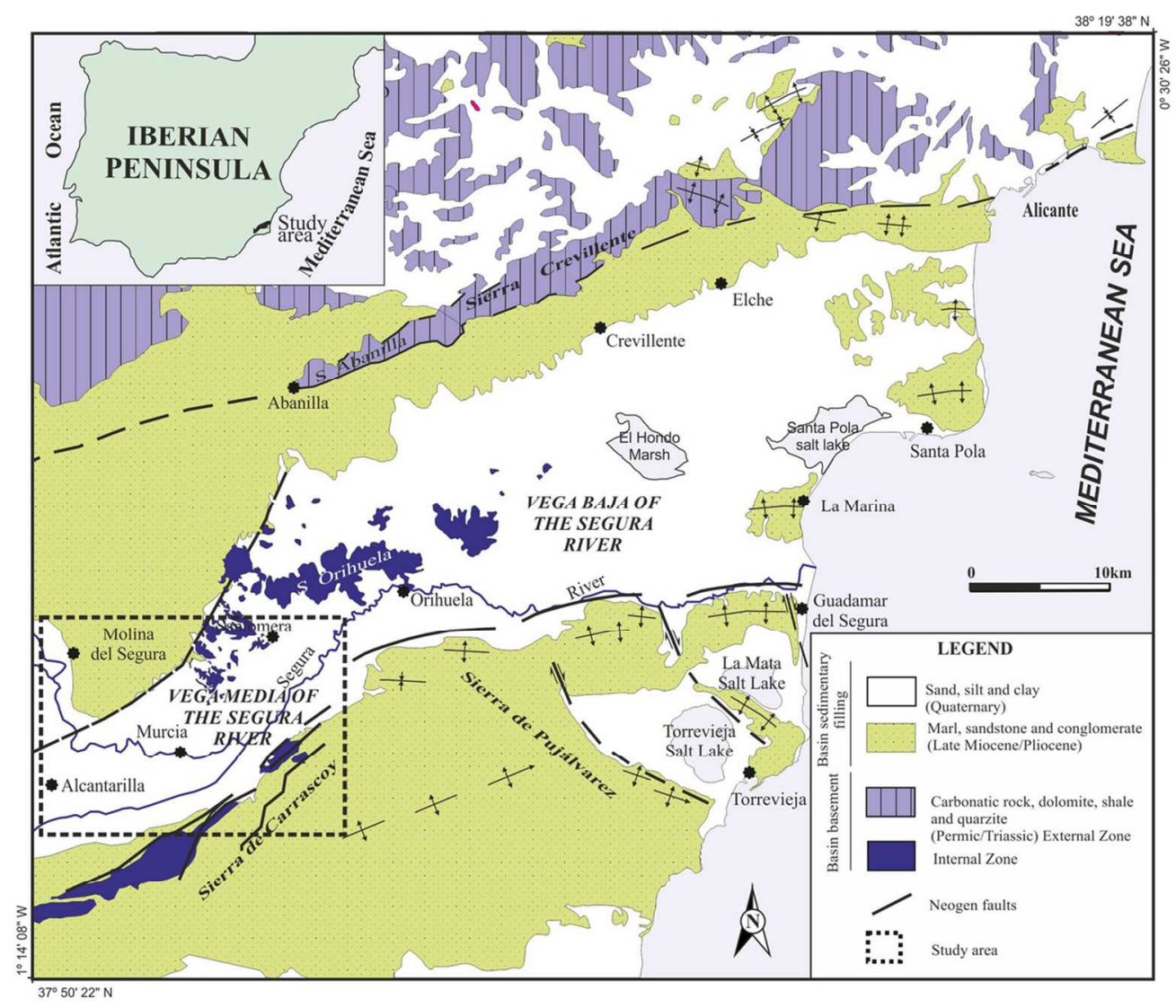

Fig. 1. Geological setting of the Vega Baja and Media of the Segura River Basin (based on Montenat 1977). $108 \times 93 \mathrm{~mm}(300 \times 300 \mathrm{DPI})$ 

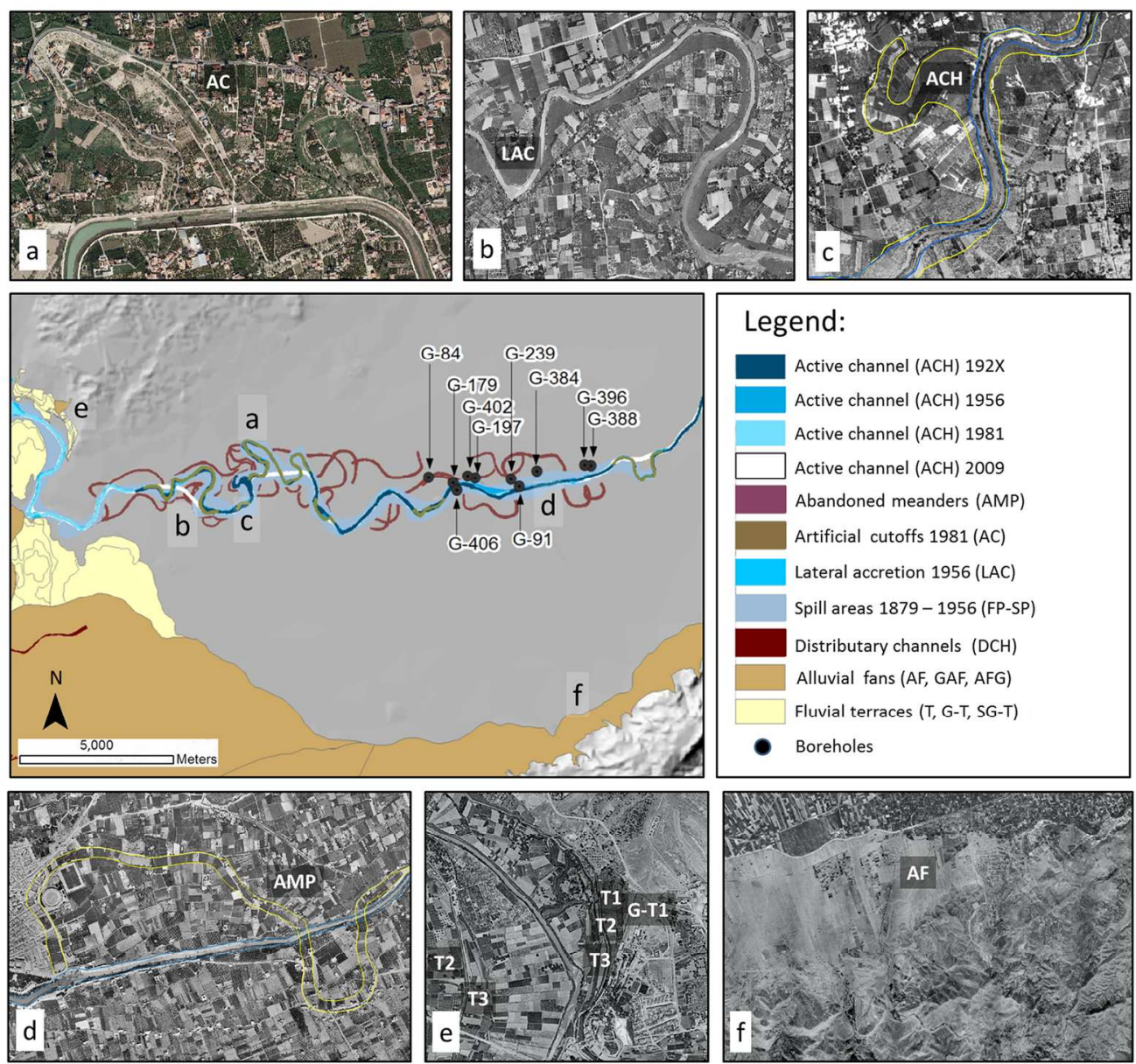

Fig. 2. Aerial photographs showing representative alluvial units in the study area: a) artificial cut-offs (AC);

b) lateral accretion zones (LAC); c) and d) abandoned meanders before channelization (AMP); e) fluvial terraces ( $(T$ and $G-T), f)$ alluvial fans (AF). Borehole codes correspond to lithology logs in Fig. 5. $150 \times 141 \mathrm{~mm}(300 \times 300 \mathrm{DPI})$ 


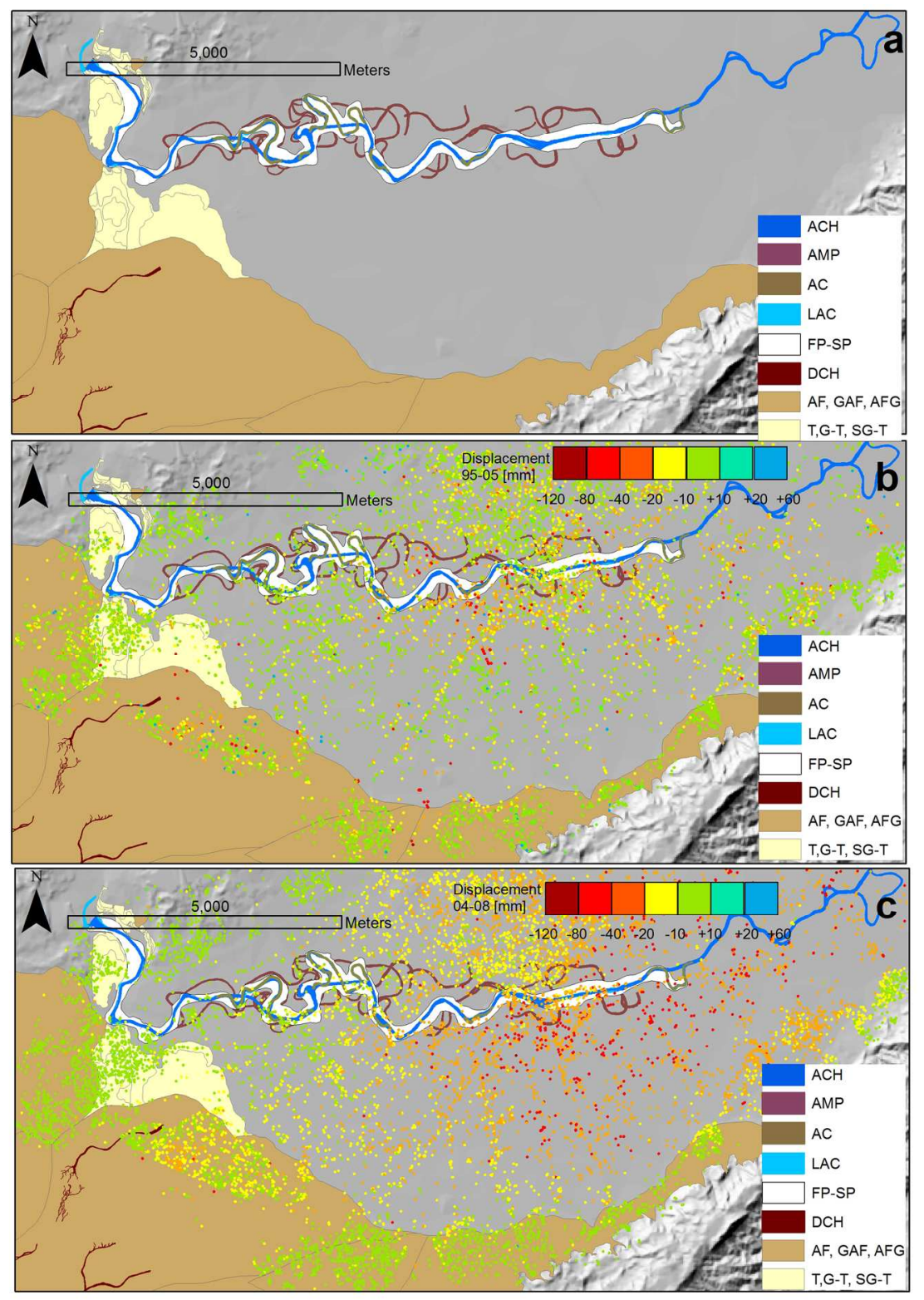

Fig. 3. (Upper) Mapped geomorphological units. (Middle) Overlaying of A-DInSAR data (1995-2005) and geomorphological units. (Lower) Overlaying of A-DInSAR data (2004-2008) and alluvial units. $148 \times 209 \mathrm{~mm}(300 \times 300 \mathrm{DPI})$ 


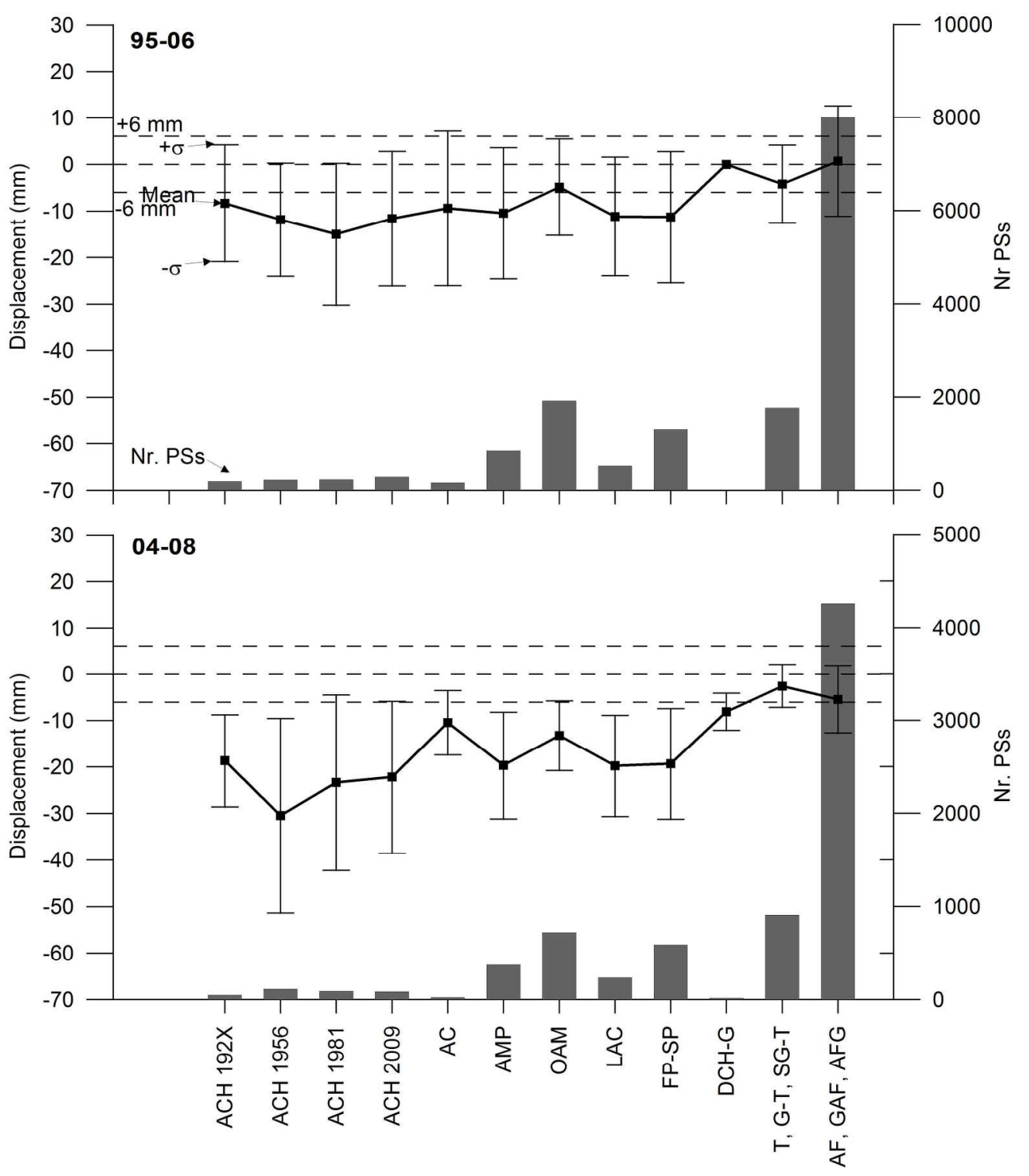

Fig. 4. InSAR displacements of the different mapped alluvial units for the two studied periods (1995-2006 and 2004-2008). $\sigma$ is the standard deviation and Nr. PS is the number of available Persistent Scatterers for each alluvial unit. $225 \times 257 \mathrm{~mm}(300 \times 300 \mathrm{DPI})$ 


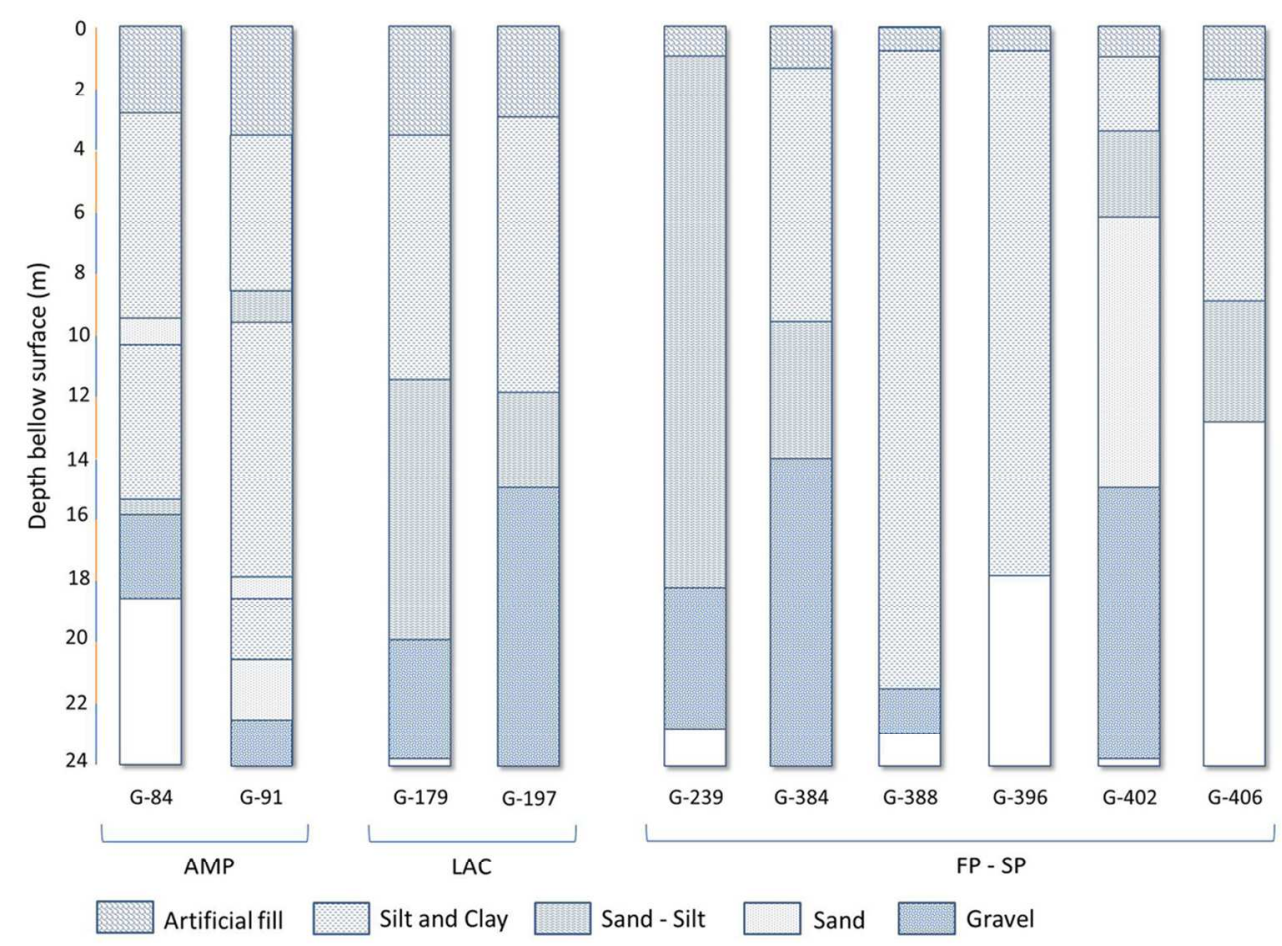

Fig. 5. Lithostratigraphic descriptions of boreholes drilled on alluvial units AMP, LAC y FS-SP. Source: Tomás et al. (2009). See location of boreholes in Fig. 2. $99 \times 78 \mathrm{~mm}(300 \times 300 \mathrm{DPI})$ 

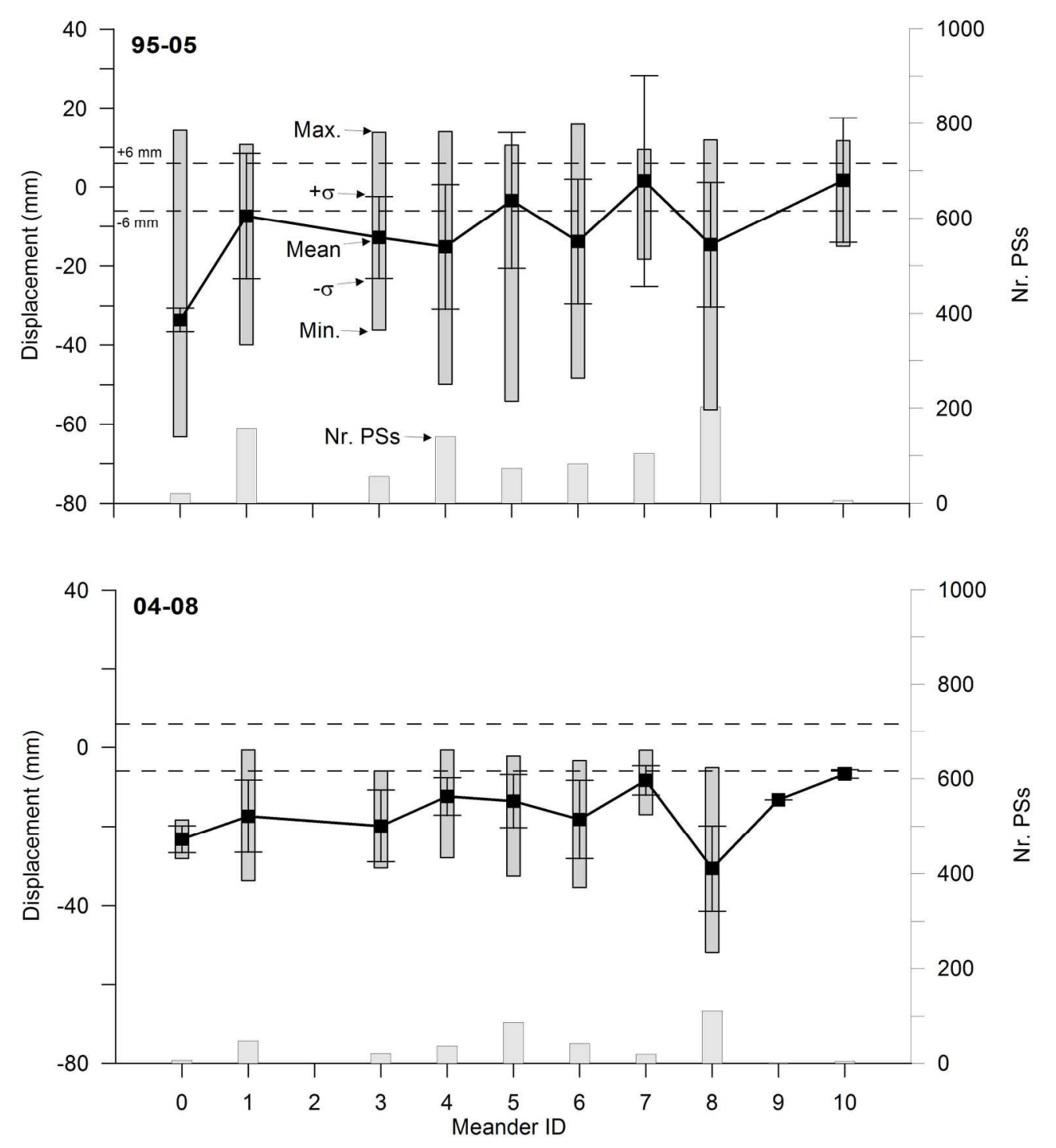

Fig. 6. InSAR displacements of the different mapped meanders (AMP) for the two studied periods (19952006 and 2004-2008). $\sigma$ is the standard deviation and Nr. PS is the number of available Persistent Scatterers for each geomorphological unit. $215 \times 237 \mathrm{~mm}(300 \times 300 \mathrm{DPI})$ 

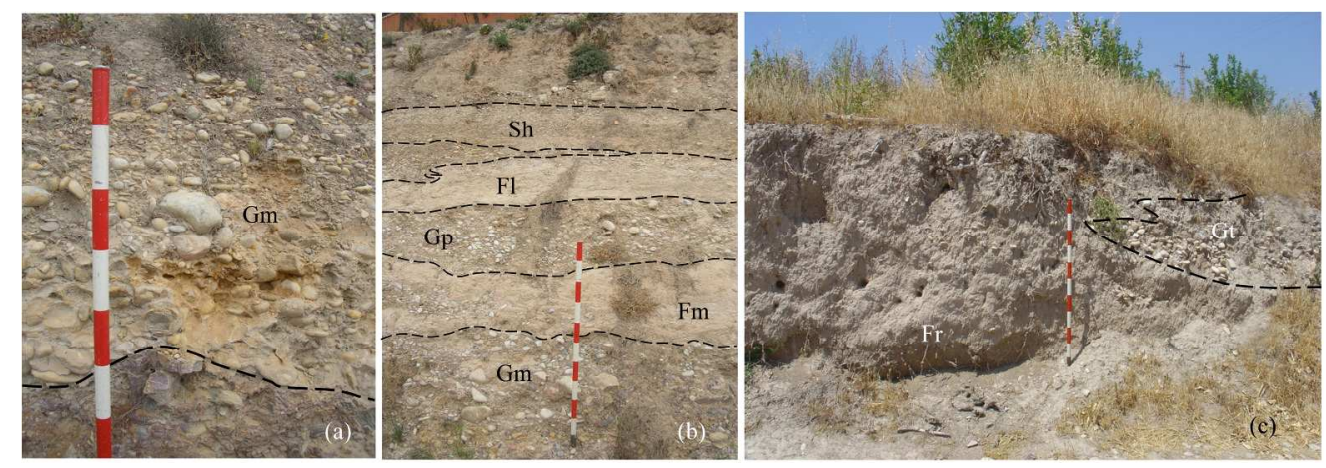

Fig. 7. (a) Base of Terrace T1: Gm facies on continental conglomerates of the upper Miocene; (b) sedimentary series in T2, from wall to ceiling: $\mathrm{Gm}, \mathrm{Fm}, \mathrm{Gp}, \mathrm{Fl}, \mathrm{Sh}$; (c) T3 terrace: Fr facies in lateral contact with a Gt deposit.

$254 \times 87 \mathrm{~mm}(300 \times 300 \mathrm{DPI})$ 

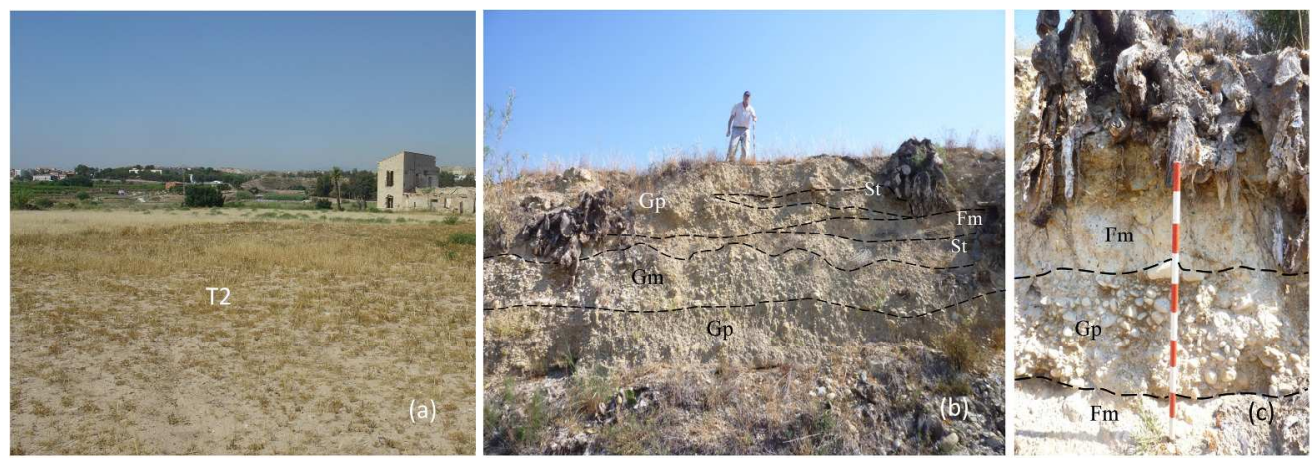

Fig. 8. (a) Terrace surface T2; (b) Sedimentary series in T2 with a predominance of Gp, St and Fm facies; (c) a detail of picture (b): Gp facies inserted between Fm deposits. $254 \times 87 \mathrm{~mm}(300 \times 300 \mathrm{DPI})$ 

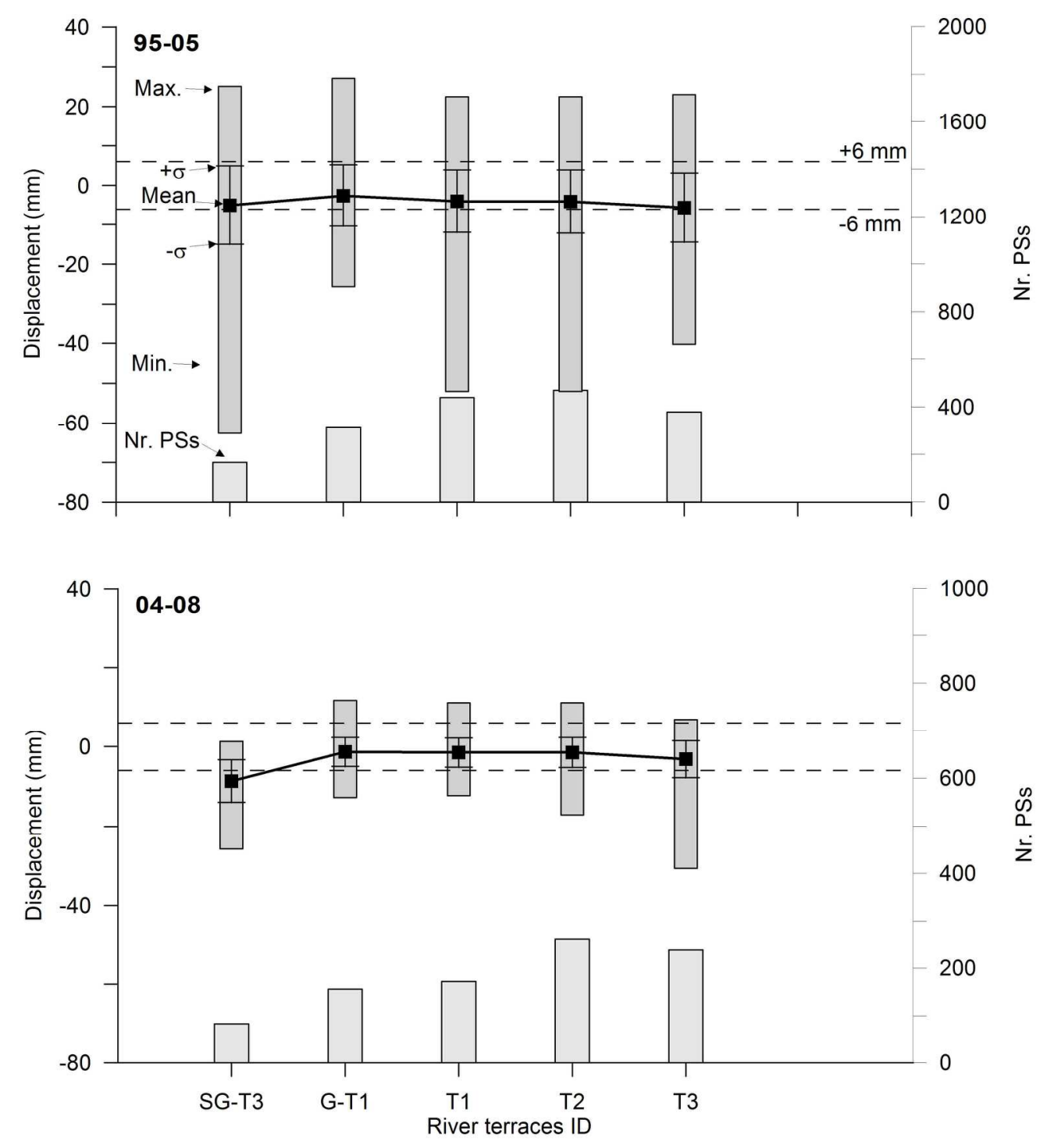

Fig. 9. InSAR displacements of the different mapped river terraces. $\sigma$ is the standard deviation and $\mathrm{Nr}$. PS is the number of available Persistent Scatterers for each geomorphological unit. $215 \times 237 \mathrm{~mm}(300 \times 300 \mathrm{DPI})$ 

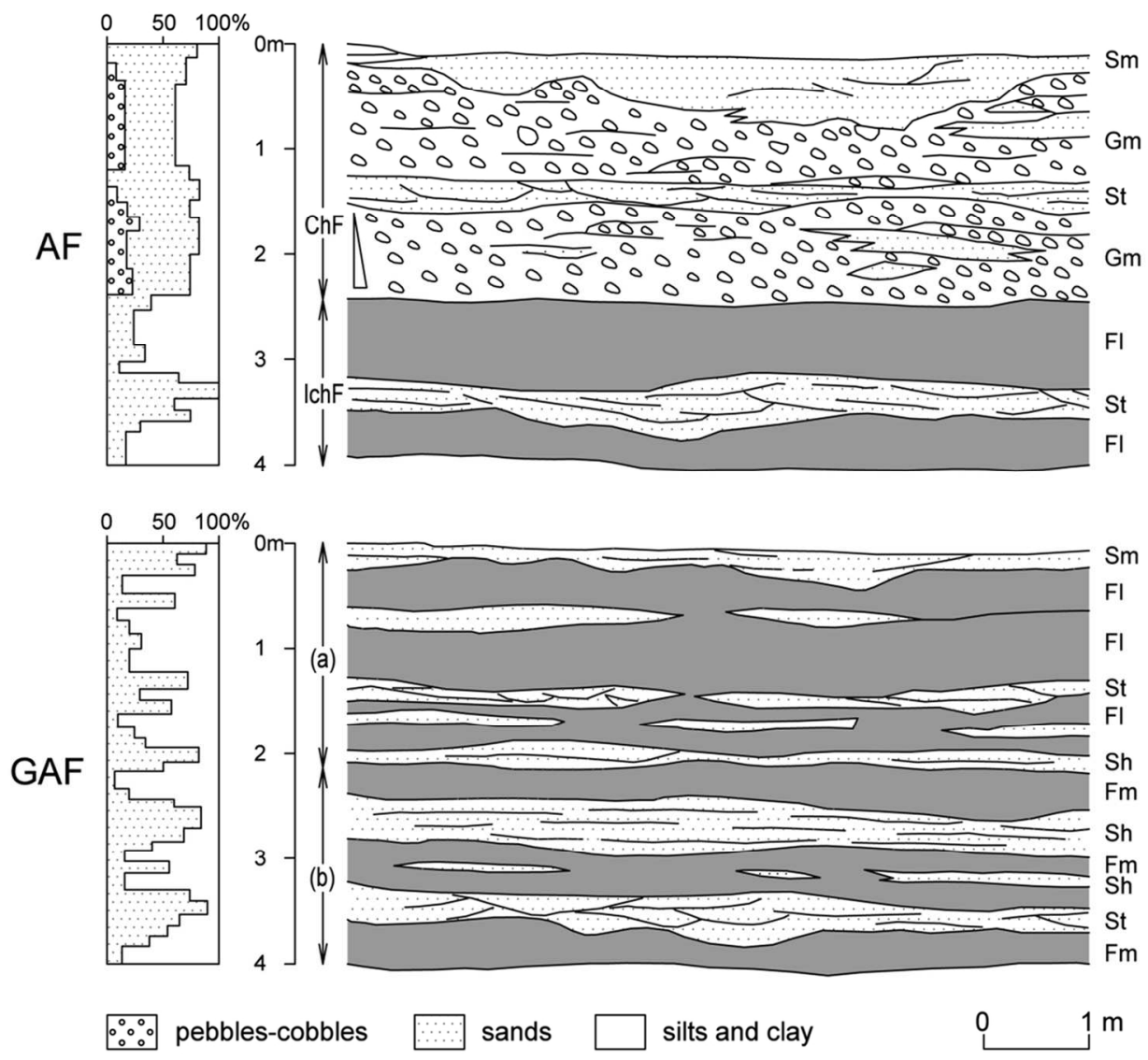

Fig. 10. Typical facies from basal areas of Carrascoy alluvial fans (AF) and inflow area of the Guadalentin alluvial fan in the Segura river (GAF). ChF, channel facies; IchF, interchannel facies. Note that in GAF, (a) the series are predominantly composed of silty-clays layers and in GAF (b) are mainly composed of channel and interchannel deposits. $118 \times 111 \mathrm{~mm}(300 \times 300 \mathrm{DPI})$ 


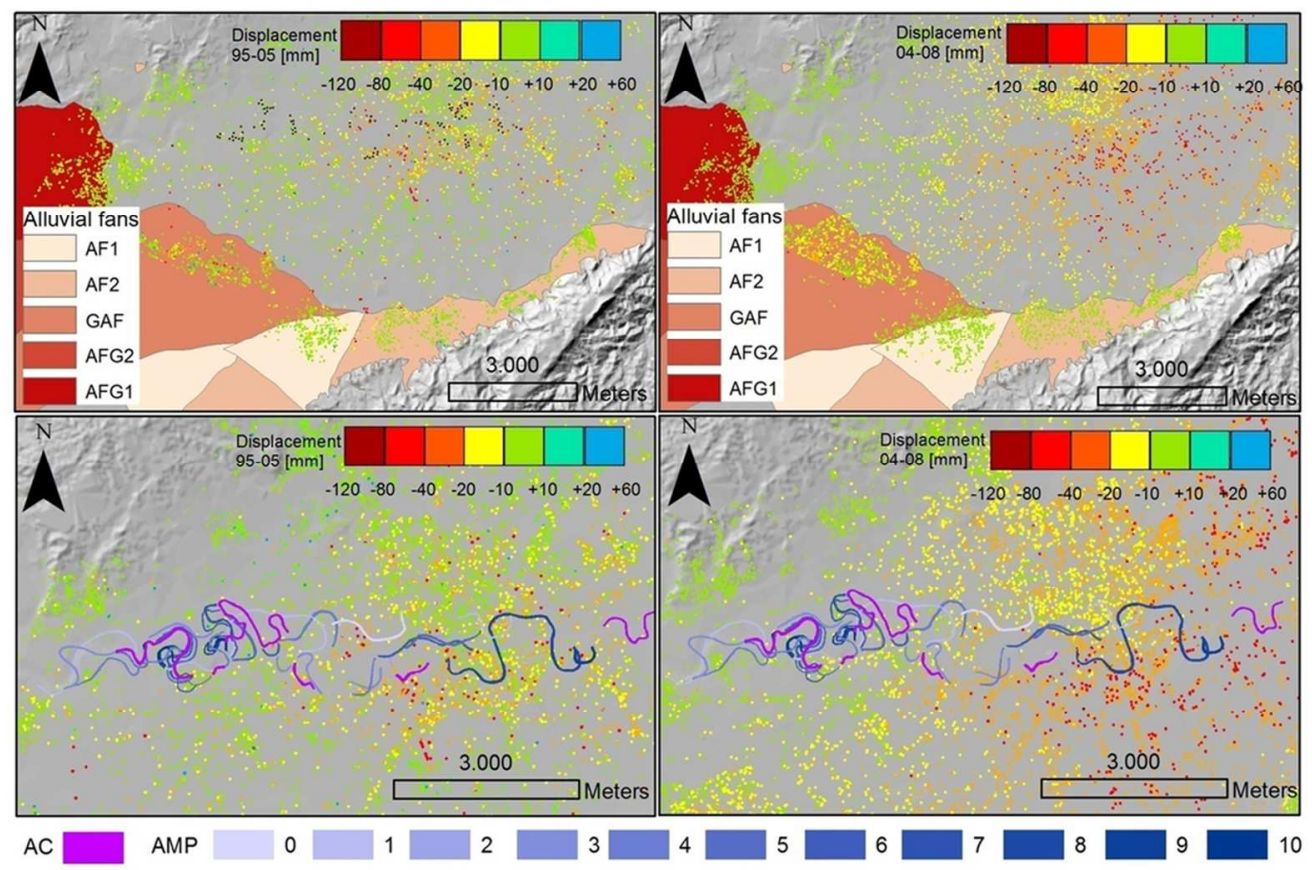

Fig. 11. Left: overlaying of InSAR data (1995-2005) with alluvial fan units (upper) and abandoned meander units (lower). Right: overlaying of InSAR data (2004-2008) with alluvial fan units (upper) and abandoned meander units (lower).

$96 \times 73 \mathrm{~mm}(300 \times 300 \mathrm{DPI})$ 

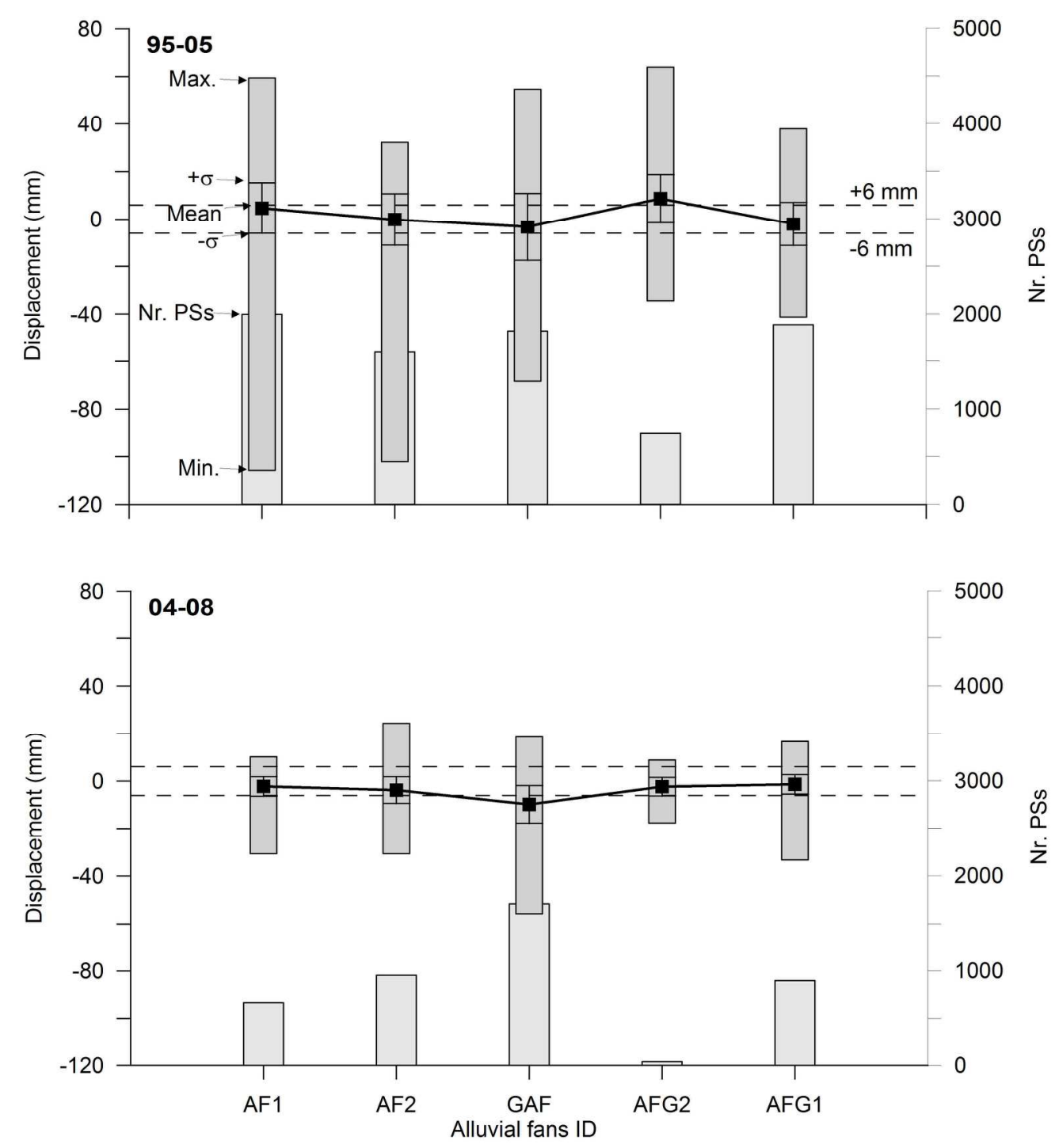

Fig. 12. InSAR displacements of the different mapped alluvial fans (AF) for the two studied periods (19952006 and 2004-2008). $\sigma$ is the standard deviation and Nr. PS is the number of available Persistent Scatterers for each geomorphological unit. $215 \times 234 \mathrm{~mm}(300 \times 300 \mathrm{DPI})$ 